\title{
RIGHTS AND RESPONSIBILITIES IN THE MUTUAL FUND
}

\author{
NATHAN D. LOBELL†
}

IN recent months several significant decisions involving shareholders' rights in mutual funds have been rendered, ${ }^{1}$ and the large number of currently pending actions by shareholders of mutual funds will afford more decisions in the immediate future. ${ }^{2}$ The opinions issued thus far show little sign that the courts have been given an understanding of the nature of the institution with which they are dealing or of the consequences of their decisions to that institution. $^{3}$ Since fund assets now stand at $\$ 20$ billion, owned in 5 million accounts, ${ }^{4}$ these consequences can be far reaching indeed.

An inquiry into mutual fund shareholders' rights is by its nature an inquiry into the duties correlative to those rights. This article will deal principally with the correlative duties of fund directors. ${ }^{5}$ In a previous article the author referred to the duties of mutual fund directors as "one of the shadowlands" of mutual fund law. ${ }^{6}$ As we penetrate the shadowland we will find that mutual

$\dagger$ Member, New York Bar. Former Executive Adviser to the SEC.

1. Brouk v. Managed Funds, Inc., 286 F.2d 901 (8th Cir. 1961) ; Brown v. Bullock, Civil No. 60-3106, S.D.N.Y., March 9, 1961; Taussig v. Wellington Fund, Inc., 187 F. Supp. 179 (D. Del. 1960); Meiselman v. Eberstadt, Civil No. 1345, Del. Ch., May 4, 1961.

2. It was estimated recently by the General Counsel of the Securities and Exchange Commission that fifty-two fund shareholder actions are now pending in various state and federal courts. See Transcript of Oral Argument, April 7, 1961, p. 101A, Brown v. Bullock, supra note 1. Despite incidental differences, an essential element of complaint in all of these pending actions is the fee of advisers serving funds under contract. Of the three major decisions noted herein, only the Brown and Meiselman cases deal directly with this issue. The Taussig case involved the right of shareholders to complain of an adviser who created a new fund with a name similar to that of the fund whose shares were held by the complaining shareholder. The Brouk case involved a complaint about various alleged malpractices of an adviser in the operation of the fund. All the cases involve questions as to the scope of the duties of fund directors.

3. It is the author's view that in attempting to define the scope of responsibility of directors the courts have uttered ratio decidendi which, if taken seriously, would destroy the continuity of investment policy expected by shareholders, as in Taussig $v$. Wellington; or immunize directors from even minimal responsibility for detecting and stopping an adviser's malpractice, as in Brouk v. Managed Funds; or substitute the director and the court for the shareholder in matters of judgment uniquely within the shareholder's province, as in Broven v. Bullock and Meiselman v. Eberstadt.

4. The actual number of shareholders, as distinguished from shareholder accounts, is estimated at about 3 million by the National Association of Investment Companies.

5. So far, the problems that have arisen in litigation relate almost exclusively to a particular aspect of directors' responsibilities, i.e., as overseers of the adviser. In view of the fact that investing is the main business of the mutual fund and is the adviser's prime responsibility under his contract with the fund, the likelihood is that this aspect of directors' responsibilities will continue to dominate judicial attention.

6. Lobell, The Mutual Fund: A Structural Analysis, 47 VA. L. Rev. 181, 188 (1961) [hereinafter cited as Lobell]. 
fund shareholders, directors and advisers ${ }^{7}$ are a triad whose interrelations are the fabric of the fund as an operating institution and whose relative rights and duties must be determined in the light of what these people do and do not do, can and can not do, may or may not legitimately expect of each other.

A lawyer researching a case involving the liabilities of directors of an ordinary business corporation may scan through the precedents involving other ordinary companies, confident that law for the directors of one company is law for the directors of the others. It is the thesis of this article that if the law of ordinary business corporations is indiscriminately applied to mutual funds, the result might be a distorted caricature of good sense and justice.

Why is this so? Perhaps the best way of approaching an answer is to appraise the mutual fund as a social fact and to understand it as a nexus of social forces.

\section{The Background of the Mutual Fund}

A society which creates abundant savings is in need of methods by which such savings may be fruitfully employed. The modern mutual fund is designed as a response to that need. Some funds originated as natural extensions of private advisory services ${ }^{8}$ some were the creation of people who early sensed the power, timeliness and salability of the fund idea and invested many years and dollars to promote it. ${ }^{9}$ But the desire to make money for their shareholders and themselves was a common attribute of all these men and the emergence of a new social phenomenon was one of the results of their efforts.

To early fund founders it seemed natural to include in their constituent documents the kinds of restrictions on management which rendered these new

7. Variously referred to in fund affairs as the "management company" or "sponsormanager" or "sponsor-adviser," the reference here is to the "investment adviser" as defined in $\S 2$ (a) (19) of the Investment Company Act of 1940, 54 Stat. 793 (1940), 15 U.S.C. $\S 80 a-2(a)$ (19) (1958). This is the person or company "who pursuant to contract ... regularly furnishes advice ... with respect to the desirability of investing in, purchasing or selling securities ... or is empowered to determine what securities . . . shall be purchased or sold. ..." Ibid.

8. See Testimony of Charles Eaton, Hearings on S. 3580 Before a Subcommittee of the Senate Committee on Banking and Currency, Part I, 76th Cong., 3d Sess. 600 (1940).

9. "Answer. From my experience I came to the conclusion that an investor needed three things in his economic life. I felt in order of importance he probably needed insurance first; second, he needed a reasonable rainy day bank account; and I felt the savings banks we had in this country provided the first and our insurance company provided the second, or perhaps vice versa. When a man had gotten to a point in life where he could become an investor there was really no sound investment medium available for him; the best he could do was to buy an individual stock or individual bond, and it did not work very well. In some of my studies the English investment trust had been called to my attention. I found the investor would invariably buy the wrong stock because he wanted a high yield. I came to the conclusion that that was unsound. So it was a question of providing a medium for the investor. I believed it could grow into a tremendously large business, because if you were going to ask the average individual the simple question: "What can I do for you?' that you would more than anything else be convinced that he would prob- 
combined accounts analogous to the traditional client-adviser relation ${ }^{10}-$ for, as they saw it, they were doing no more (or less) than making mass service possible by adapting tradition to modern needs. ${ }^{11}$

Despite its size and the large and growing variety of shareholder services, such as systematic accumulation and withdrawal plans, plan insurance and automatic reinvestments of distributions, the mutual fund remains, in essence, the means of extending services that could not be provided as broadly on a private basis without great difficulty and expense.

It is this history which explains a phenomenon common to almost all funds but not prevalent elsewhere-the advisory contract. This is analogous to the individual service arrangement which a private adviser makes with each client. In the context of the fund the creation and termination of this arrangement is approximated by the purchase and redemption of fund shares. As an attribute of fund structure, the contract was so deeply ingrained by history and tradition that the Investment Company Act of $1940^{12}$-designed as the major federal compendium of fund regulation-assumes the contract as the means by which a fund is served by its adviser and requires the contract to conform to a prescribed pattern in terms of the method of its adoption and cancellation, its duration, and certain other aspects. ${ }^{13}$ Another example of this tendency in the modern fund is the practice of having the adviser bear many of the costs of operating the fund. This helps to alleviate the burden of the fund, as a separate entity, on the shareholder, thus approximating the relationship between the private investment adviser and his client.

\section{The Fund Shareholder}

We know that in 1958 a typical holder of fund shares in a regular account was somewhat above 50 years of age, held fund shares valued at over $\$ 4,000$,

ably answer, 'Help me to get somewhere financially.' So it seemed to me I had at least a very large potential market. Out of that grew the idea of the Massachusetts Investors Trust.

"Question. How long did it take you before you could get anybody interested?

"Answer. Three or four years.

"Question. Then who picked up the idea?

"Answer. Learoyd, Foster \& Co.

"Question. As a result of that the Massachusetts Investors Trust was formed? Is that right?

"Answer. That is right."

This is the testimony of Edward Leffler, one of the organizers of the oldest and largest mutual fund in the country. Quoted in SEC, Investarent TRUSTS AND Investarent CosspaNIES, PART ONe 102 (1940). 604.

10. See, e.g., Testimony of Charles Eaton, Hearings on $S .3580$, supra note 8, at 595-

11. Ibid.

12. 54 Stat. $789(1940)$, as amended, 15 U.S.C. $\$ \S 80 \mathrm{a}-1$ to -52 (1958).

13. Section 15, Investment Company Act of 1940 . See discussion beginning at note $\mathbf{7 5}$ infra and accompanying text. 
owned over $\$ 8,000$ of general market securities, had a bond and savings bank account of close to $\$ 3,500$ and somewhat less than $\$ 10,000$ of insurance. He was inclined to hold fund shares in more than one fund-apparently apportioning his fund investments according to an appraisal of his own objectives. In a group of 100 of these shareholders about 30 were likely to be women and 70 men-and of those men about 45 were likely to be professionals or in executive-administrative positions. ${ }^{14}$

We do not know how many of these people explored means of retaining full-time professional investment supervision other than through mutual funds. Nor do we know how many of them read the prospectus and other information available to them before investing. We can be sure that most of them were "sold" by a fund share dealer's representative with techniques of "prospect development" originating in the insurance field and adapted to fund selling.

At the same time we do know that if Mr. Smith, a hypothetical shareholder, had taken the pains to explore the alternatives, and had made his fund investment as a result, he may well have had approximately the following experience: With $\$ 10,000$ to invest in common stocks, Mr. Smith believed that prudent investing calls for care in the selection of stocks, for diversification and for alert watchfulness over one's holdings in changing times. Unable to fill these needs himself he decided to turn his $\$ 10,000$ account over to a professional. Several investment firms refused to assume full-time supervision of his small account, others fixed fees which would absorb a large portion of his expected investment income. All advised him that the account was too small to afford wide diversification except in low-priced speculations. One of the firms he consulted was an investment banking house which was also investment adviser to a mutual fund. ${ }^{15} \mathrm{He}$ discovered that by purchasing the fund's shares ${ }^{16}$ he could benefit from the full time investment management

14. National Ass'n of Investment Companies, "The Mutual Fund Shareholder," 1958.

15. Various traditional banking houses such as Lehman Brothers, Lazard Freres \& Co., Coffin \& Burr, Inc., Carl M. Loeb, Rhoades \& Co., F. Eberstadt \& Co., are founders and advisers of mutual funds. Some funds were founded and are served as advisers by houses specializing in investment counselling-such as Eaton \& Howard, Inc. and Scudder, Stevens \& Clark. Others are served by advisers who have undertaken to specialize completely in fund management. Edgar Lawrence Smith, a New York analyst, whose ConuroN Stocks As Long Term Investarents, published in 1924, was the fountainhead of the new view of common stocks as an essential element of prudently managed portfolios, formed Investment Management Company in 1924 with a group of co-sponsors for the specific purpose of putting his philosophy to practical use through mutual fund management. Fundamental Investors, Inc., a $\$ 600$ million common-stock fund is still managed by a successor to Investment Management Company under the chairmanship of a member of the original founding group.

16. The purchase may involve the payment of a sales charge. A relatively small number of funds distribute their shares without sales charge. Others use "principal underwriters" serving under contract with the fund, and their shares are sold with sales charges up to $83 / 4 \%$ on small lump-sum purchases and $9 \%$ on installment plan purchases. Cf. Section 15(b), Investment Company Act of 1940, 54 Stat. 812 (1940), 15 U.S.C. $\$ 80 a-15$ (b) (1958). 
service rendered to the fund by the adviser at a fee cost to himself of half or less than half of that charged for private counselling. ${ }^{17}$ In addition he would have an interest in a much more widely diversified investment portfolio than he could afford in his single account. ${ }^{18} \mathrm{He}$ could, as could any private client of the house, terminate its service at any time-in his case by having his shares redeemed for their current value in cash and without charge. ${ }^{19}$

$\mathrm{Mr}$. Smith was given a prospectus which described the investment objectives of the fund, its security holdings, the performance of the investment adviser in management of the fund over past years, the adviser's fee, and other information. As a shareholder of the fund $\mathrm{Mr}$. Smith receives periodic reports of performance ${ }^{20}$ and has available to him quotations on his shares published in daily newspapers. ${ }^{21}$

Apart from obedience to basic standards of honesty in handling and full accounting for his money by the fund management, Mr. Smith expects the same level of skill and degree of care to go into the supervision of his fund account as he would if his account were privately managed. He expects a continuity of service from the adviser whom he chose to manage his account through the fund. He would not want to wake one morning and find his money in the hands of a stranger. He expects a continuity of policy in fund management-no radical changes in the degree of risk he assumed when he bought the shares-just as he would expect a private adviser to continue following an instructed policy of risk taking. ${ }^{22}$

17. While there is a wide variety of charges (and types of charge) for private counselling, recent plans for private management of small accounts (up to $\$ 25,000$ ) call for fees of as high as $2 \%$ of assets in the account. This is four times higher than the usual $1 / 2$ of $1 \%$ advisory charge called for in fund advisory contracts. See, e.g., Plan of Danforth Associates, N.Y. Times, March 26, 1961, \& 3 (financial), p. F7, col. 5.

18. Shares selling at $\$ 50$ per share and traded in 100 share round lots permit only 2 issues to be held in a $\$ 10,000$ portfolio without involving the extra brokerage for odd-lot purchases and sales. The typical mutual fund holds anywhere from 60 to over 100 stocks.

19. A very few funds impose a small "redemption fee." Most have no redemption fee. It should be noted that the redemption for cash of a fund share is, for tax purposes, a "realization" which involves capital gain or loss tax consequences.

20. See Investment Company Act of 1940 \& 30, 54 Stat. 838 (1940), 15 U.S.C. $\S 80 \mathrm{a}-$ 30 (1958), and SEC Rules 30a-1 to 30f-2, 17 L.F.R. $\$ \$ 270.30 \mathrm{a}-1$ to $270.30 \mathrm{f}-2$ (1949).

21. Quotations are frequently stated as "bid" and "asked" prices. The "bid" price is the actual asset value, the amount available on redemption where no redemption fee is involved. The "asked" price is the "bid" price plus the sales charge. These prices, for the purpose of sale and redemption, are calculated by funds twice each business day. For a discussion of the background of the twice-a-day pricing practice, see Greene, The Uniform Offering Price of Mutual Fund Shares under the Investment Company Act of 1940, 37 U. DET. L.J. 369 (1960).

22. Mr. Smith is far more typical than many observers tend to believe. The number of fund accounts held by trustees, institutions, business organizations and other substantial and sophisticated investors has increased continually and as of the last quarter of 1960 stood at approximately 220,000 (as against 165,000 in the prior year). In recent years, impelled in large part by tax considerations, owners of private holding companies have merged 


\section{The Conceptual Models}

The aggregate of Mr. Smith's expectations and understandings is embodied in the simple formula of stewardship between himself and the adviser he chose for the management of his money through the fund. If that understanding is typical of the fund investor, then the fund is truly the matrix of two social drives (of the founder adviser and of the shareholder) expressing themselves in a relation that the law classically recognizes as that of a trust.

Mr. Smith's fund, like most others, happens to be a corporation. ${ }^{23}$ It has a ten-man board of directors of which four members are affiliated with the advisory house-the founder of the fund. ${ }^{24}$ The adviser serves under a contract with the fund, a contract which has been renewed each year by the board of directors or by shareholders since the fund's formation. ${ }^{25}$ However, not all funds are corporations. And of those which are trusts some do not have boards of trustees. ${ }^{26}$ To $\mathrm{Mr}$. Smith it makes little difference what form the fund takes and he would be surprised to hear that his rights are enhanced or diminished depending on whether the fund is or is not a corporation, or does or does not have a board. In any case, since the adviser may serve the fund only under a written contract, ${ }^{27}$ it is obvious that while the fund is the nexus of the relation of stewardship between the adviser and the shareholder, the advisory contract is its life-line.

them with mutual funds in tax-free reorganizations. Single fund accounts of as large as $\$ 3$ million each have been so created. It may be taken for granted that these and many smaller account holders investigated carefully before investing in a particular fund. However, even the less careful holder who knows of the fund only by its name, its objectives and performance record assumes a continuity of the adviser and his policy when he selects the fund's shares. The source of much erroneous thinking about funds is the failure to comprehend that what masquerades as an appeal to "high standards" of fund management may be no more than an improper assumption that an investor's choice is a random exercise of ignorance and that it should give way to a paternalistically determined alternative choice "better" for the investor than the one he made himself. This is in direct contrast with the philosophy of disclosure which respects the investor's freedom of choice and attempts to make his decision an informed act of will.

23. The majority of mutual funds are corporations.

24. Representation of the adviser is limited to four out of ten members of a fund's board of directors or trustees whenever the adviser is, or is affiliated with, the fund's principal underwriter. Investment Company Act of $1940 \S 10,54$ Stat. 806 (1940), 15 U.S.C. § 80a10 (1958).

25. No fund contract may provide for a duration beyond two years. It may be renewed annually either by approval of shareholders as a class or by directors, including a majority of those not affiliated with the adviser. Investment Company Act of 1940 \& 15, 54 Stat. 812 (1940), 15 U.S.C. $\$$ S0a-15 (1958). Traditionally, fund advisory contracts are renewed annually.

26. Trustees are considered "directors" under the federal statute. Investment Company Act of 1940 \$2(a) (12), 54 Stat. 792 (1940), 15 U.S.C. $\$ 80 a-2(a)$ (12) (1958).

27. Section 15(a) of the Investment Company Act of 1940, 54 Stat. 812 (1940), 15 U.S.C. $\$ 80 \mathrm{a}-15$ (a) (1958). The basic requirements of the contract are discussed beginning at note 75 infra and accompanying text. 
Thus one might conceive of the relation of a private investment counsellor with his client in this manner:

The Account

Investor

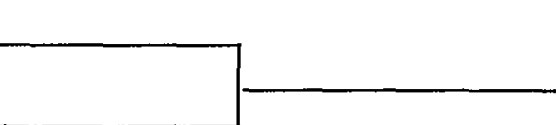

Counsellor

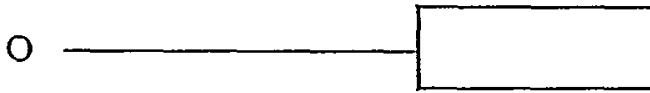

$\Delta$

the relation of a fund shareholder to the adviser in a fund without a board as follows :

Shareholder

The Fund

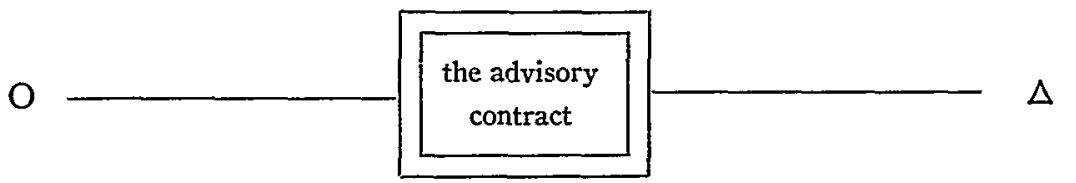

and their relationship in a fund with a board, somewhat as follows:

The Fund

Shareholder

Adviser

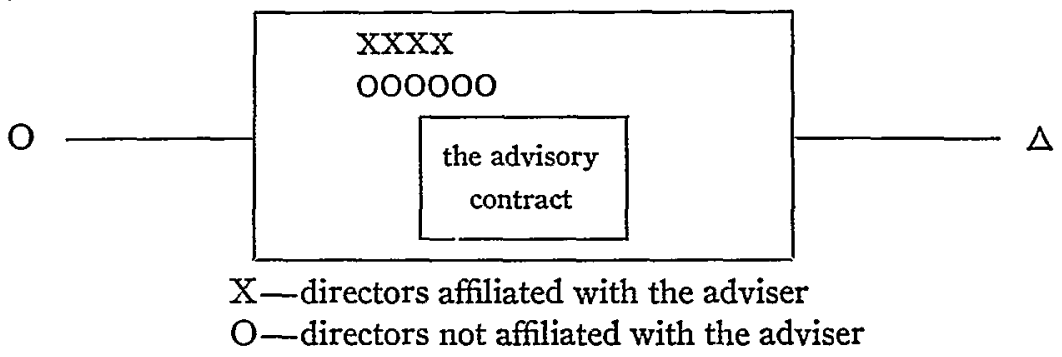

For most purposes, however, one conceives of the relation in an ordinary corporation thus :

Stockholder

$$
\text { The Corporation }
$$

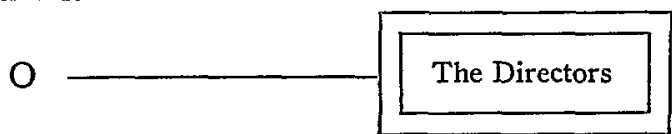

It will be noted that the conceptual model of the typical corporation, internally managed, involves a direct line of relationship between the shareholders and directors. In this relationship the total range of enforceable expectations and understandings of the shareholder, as such, is presumably reflected in a corresponding set of functions and duties of directors. Directors of the typical corporation are plenipotentiaries in corporate managementwhether the directors perform functions alone or delegate those functions to others. $^{28}$

28. In one sense, directors' powers are "original," "received" from the state in the act of incorporation. However one views the source of directors' power, the beneficiaries of its exercise, and those empowered to pursue remedies against them, are the shareholders. 
In the simple model of the private client-investment counsellor relationship and in that of the fund with no board there is obviously no place for a board of directors. It is to the adviser that the investor looks for the management of his money and the total range of enforceable expectations and understandings in the arrangement is presumably matched by corresponding responsibilities and duties of the adviser.

However, in the corporate mutual fund (or in the fund in trust form which has a board of trustees) served by an adviser under contract the directors do appear at the apex of the relationship. What are their responsibilities? Is there any warrant for believing that they are of a different scope or level from those of the typical corporate director? In exploring this question we will refer to basic doctrine and to unique provisions of statutory law applicable to mutual funds. But the perspective of our Mr. Smith provides the common sense approach. In his view responsibilities of directors are neither so broad as to belie his understanding that it was to the adviser that he was entrusting the management of his account, nor so narrow as to make the directors in fact rubber stamps or dummies.

The truth is somewhere in between. To define it with more precision, consistently with the pattern of legislation affecting funds, and with the rational administration of funds, requires us to look not merely to the law of directors' liability but to the ethical predicates behind it. Should Miss Marilyn Monroe raise public capital for new productions by forming the M.M. Corporation and issuing its shares publicly, the heart of such a venture would be the corporation's contract with Miss Monroe. Whatever other functions one might predicate in the directors of this type of corporation they do not embrace a freedom to fire Miss Monroe because Gloria Gorgeous is willing to serve for a smaller percentage, or because Miss Monroe refuses to dicker with the directors for a percentage of profits lower than that fixed in her contract and disclosed to and accepted by every participating shareholder. ${ }^{29}$ On the other hand, there is just as little doubt that the directors do have an obligation to see to it that Miss Monroe obeys faithfully the terms of her contract-as, for example, making the number of films specified within the times specified. In reaching these conclusions one works from the sense and meaning of the relationship to judgments about its attributes-not from any predetermined set of ideas derived from the form in which the relationships are cast.

In the same sense the reader will have realized that the conceptual models illustrated above, if they justify differences in the scope or level of duties, must

29. If these problems were litigated there would seem to be no reason for reaching different conclusions even if it were proved that, for some reason or other, Miss Monroe "dominated" the board or that the board members were in "collusion" with her. Cf. the discussion of Brozen v. Bullock beginning at note 85 infra and accompanying text. The problem of what fund directors may or may not do in respect of the advisory contract arises in fund litigation partly because, as we shall note, the statute gives directors the power to veto a renewal of, or to cancel, an advisory contract without specifying the standards on which such action should be based. 
assume a legal predicate broad enough to yield each model as a special case of the general truth. This basis was classically stated by Justice Earl as follows:

When one deposits money in a savings bank, or takes stock in a corporation, thus divesting himself of the immediate control of his property, he expects and has the right to expect, that the trustees or directors, who are chosen to take his place in the management and control of his property, will exercise ordinary care and prudence in the trusts committed to them. ... Like a mandatary, to whom he [the director or trustee] has been likened, he is bound, not only to exercise proper care and diligence, but ordinary skill and judgment. ${ }^{30}$

Justice Earl deals here with both the ethical basis and the legal levels of directors' duties. Later opinions have couched their descriptions of the level of duties in more exacting terms, ${ }^{31}$ but none has, or indeed could, change the ethical basis for predication of duties in an "open" society. ${ }^{32}$ The ethically operative elements of the quoted statement are:

a. legitimate expectations arising from the

b. choosing and mandating of another to take the settlor's place in the

c. control of property of whose immediate control the settlor

d. divests himself. ${ }^{33}$

Describing the triggers that release fiduciary duties in almost any context involving freedom of a creator of a trust to choose his mandatary and to determine the scope of the mandate, the doctrine is broad enough to yield meaningful conclusions in specific applications to the models we have illustrated. ${ }^{34}$ If

30. Hun v. Cary, 82 N.Y. 65, 71, 73-74 (1880). (1939).

31. See, e.g., the opinion of Mr. Justice Douglas in Pepper v. Litton, 308 U.S. 295, 311

He who is in such a fiduciary position cannot serve himself first and his cestuis second. . . He cannot use his power for his personal advantage and to the detriment of the stockholders and creditors no matter how absolute in terms that power may be and no matter how meticulous he is to satisfy technical requirements. For that power is at all times subject to the equitable limitation that it may not be exercised for the aggrandizement, preference, or advantage of the fiduciary to the exciusion or detriment of the cestuis.

32. By the term "open society" we intend to designate one whose basic assumption is equality of status, which attempts through equitable rules to define the rights and duties of people in their contractual arrangements according to their intent, and which strikes down private arrangements only where obvious public policy demands it (such as contracts for white slavery) or where the assumed equality of status and bargaining power does not in fact exist (e.g., contracts with minors or with the insane, or unilateral mistakes of fact induced by misrepresentation). In contradistinction to the "open" society is the "closed" society, such as feudalism, where birth or the assumption of a status naturally carries with it rights and duties transcending individual bargains.

33. While not explicitly stated, it is assumed that the "mandatary" has undertaken the functions and thereby the responsibility of control.

34. In the private client-counsellor relationship the range of duties of the counsellor may extend far beyond the specific terms of the contract, and certain exculpatory provisions 
one is, therefore, to list a set of duties for which any fiduciary, including a mutual fund director, is chargeable, one must find a root for these duties in the doctrine.

A basic distinction is immediately apparent between those elements of a relationship as to which the creator of the trust exercises freedom of choice (and corresponding responsibility) and those elements as to which responsibility is vested in the trustee. Thus a private client who instructs his investment counsellor to maintain a low level of risk cannot be heard to complain of a low level of capital gain. A shareholder who purchases a fixed dividend preferred stock in a corporation cannot be heard to claim that the directors should declare a higher preferred dividend on the ground that they personally own common stock and are benefiting from high earnings. The settlor of a trust estate cannot be heard to complain of the fee he agreed to pay for management. The holder of a bank account cannot sue for added interest on the ground that the bank earns a surplus profit from the use of his money. In each of these cases a trust relation of some kind is established. But in all cases the creator of the trust himself has chosen or accepted terms of the relationship which are inconsistent with the responsibility he alleges. The limits of the mandate set the limits of the duties which may be derived from the mandate.

Similarly, the purchase of a mutual fund share involves certain choices which are within the ambit of freedom-and hence responsibility-of the investor. In the nature of things, he does not fix these terms by individual arrangement, but accepts or rejects them as elements of the type and terms of

of the contract may, under the doctrine of Pepper v. Litton, 308 U.S. 295 (1939), be disregarded in fixing the range of responsibilities. A parallel to that doctrine applicable to the mutual fund may be found in $\S 17(\mathrm{~h})$ of the Investment Company Act of 1940, 54 Stat. 817 (1940), 15 U.S.C. \$ 80a-17(h) (1958) which provides:

After one year from the effective date of this subchapter, neither the charter, certificate of incorporation, articles of association, indenture of trust, nor the by-laws of any registered investment company, nor any other instrument pursuant to which such a company is organized or administered, shall contain any provision which protects or purports to protect any director or officer of such company against any liability to the company or to its security holders to which he would otherwise be subject by reason of willful misfeasance, bad faith, gross negligence or reckless disregard of the duties involved in the conduct of his office.

Section 17 (i) contains identical provisions applicable to investment advisers. In the typical corporate relationship the law follows custom in deeming the directors to be plenipotentiaries in all matters not reserved for freedom of choice of the owners. As we shall observe, certain aspects of the stockholder's relation to the company are within his own choice, not creating corresponding duties in others. And the corporation may be of a type like the M.M. Corp. referred to in the text supra where, by nature of the enterprise, certain functions normally associated with the typical corporate director cannot be assumed without destroying the sense of the relationship. This is the case in the mutual fund. In the fund situation the law still has to build a set of precedents which clearly separate the mandated from unmandated responsibilities and set the levels applicable to the various mandated duties. 
service offered to him in the offering of the fund's shares. These "terms" of the relationship-the aspects of the fund preexisting the purchase of the shares, disclosed in the prospectus and presumably accepted and assented to by the purchasing shareholder-include, in part:

1. the identity of the adviser, ${ }^{36}$

2. the fee of the adviser, ${ }^{37}$

3. the stated investment objective of the fund and the degree of risk taken to achieve that objective, ${ }^{38}$ and

4. the terms and conditions, if any, of his redemption rights. ${ }^{80}$

Each of these aspects of the fund, required to be disclosed in the prospectus, is one which should enter into the total act of decision by the shareholder to purchase or not to purchase the shares initially. It is one of the aims of this article to demonstrate that the prime purpose of the disclosure requirements of federal law applicable to mutual funds is to inform the investor of these facts, among others, so that his purchase can reflect "an ... informed act of mature will."40 It would seem beyond doubt that no shareholder of a fund has standing to complain of any of these disclosed and accepted elements of the

35. The prospectus is required to contain many items of disclosure in addition to those listed here. Some of these are, by terms of the arrangement, subject to change, such as the portfolio itself. However, since the prospectus gives the fund's acquisition cost of each holding in the portfolio, it reveals the unrealized gains inherent in the portfolio and, in that sense, informs the investor of the capital gains distributions (in effect taxable returns of capital) to which he is subject. Thus the unrealized capital gain position of the fund becomes one of the accepted terms on which the investor makes his share purchase. See Schedule A of Securities Act of 1933, 48 Stat. 88 (1933), 15 U.S.C. $\$ 77 a a$ (1958).

36. The prospectus is required to set forth not only the name but the management make-up of the adviser. In describing the policy, performance and risk level of the fund it describes, in fact, the character and history of the adviser's service.

37. Summary of Management Fees-249 Mutual Funds*

\begin{tabular}{lrccc} 
Rate of annual fee & \multicolumn{2}{c}{ Funds } & \multicolumn{2}{c}{ Total Assets } \\
(as \% of net assets) & No. & $\%$ & In Millions & $\%$ \\
\hline Greater than $1 / 2$ of $1 \%$ & 67 & $26.9 \%$ & $\$ 1,766.2$ & $10.6 \%$ \\
I/2 of $1 \%$ & 145 & 58.2 & $8,610.0$ & 52.0 \\
Less than $1 / 2$ of $1 \%$ & 37 & 14.9 & $6,191.4$ & 37.4 \\
& 249 & $100.0 \%$ & $\$ 16,567.6$ & $100.0 \%$ \\
\hline
\end{tabular}

* Rates and assets as of June 30, 1960.

Source: Analysis of various prospecti.

38. While many funds may state their investment objectives in similar language, the actual degree of risk taken to achieve the objective may vary considerably and be discernible only by inspection of the portfolio-i.e., the nature of the stocks held and the relative amount of cash or cash equivalents or bonds retained in the portfolio.

39. Funds do not, as a matter of custom, make shareholders wait for cash on redemption. However, the power to do so to cover emergencies is often retained and that fact is disclosed in prospecti. If a redemption fee is charged (which is done in a small minority of funds), that fact is disclosed also.

40. Lobell 210. 
fund predating his purchase and unchanged (in terms or in material significance due to change in circumstances) since his acquisition of the shares. ${ }^{41}$

However, our hypothetical Mr. Smith's inability to find private means, at an economical fee cost, of full-time professional management and broad diversification, led him to purchase his fund shares. Rooted in his expectations and understanding was the assumption that the fund shares were a means of obtaining these advantages. $\mathrm{He}$, himself, chose the adviser who would do the managing, selected the fund for its stated policy and the risk level apparent in its portfolio and accepted the disclosed advisory fee and other terms fixed in the fund's contract with the chosen adviser. By having made the choice, he divested himself of control of his money and mandated the use of it in the hope of return through a fund investment account. Until he elects to terminate the account through redemption, control of these operational aspects of the fund is in others than himself. With that control go mandated functions and responsibilities, squarely within his legitimate expectations. These include:

1. a professional level of competence in buying and selling investment holdings in pursuit of the fund's policy;

2. a strict accounting for every penny of capital, capital gains and income;

3. the responsibility created by traditions of equity and by statute to avoid unfair advantage to fund insiders at the expense of the investor; and

4. such additional responsibilities (for instance, keeping the investor informed of the progress of the fund) as are prescribed by statute. ${ }^{42}$

In several of the decisions to be discussed the issue before the courts has involved, in one form or another, the duties of fund directors with respect to advisory fees. Whether favorable or adverse to directors, a common characteristic of these decisions is that they assume the fiduciary character of the relations focussed in the fund but skip the preliminary step of allocating rights and duties as we have here tried to do. Instead, the courts have tended to reach into the bin of concepts developed in cases involving the typical corporation and to proceed directly to apply garden-variety law to the question of directors' responsibility for management compensation.

Is this skipping of the allocation problem warranted? A court which had before it the legitimacy of a complaint by a shareholder in the M.M. Corporation ${ }^{48}$ that Miss Monroe's percentage was too high and that directors were

41. What constitutes a change of situation of sufficient scope to create a duty to change a "term" aspect of a fund is a question that has to the author's knowledge so far not been judicially decided. In any but the most extreme market crises it would seem that the fund management has neither freedom nor responsibility to make a drastic change in fund investment policy. If a crisis is urgent enough it is, in the author's opinion, within the range of management's freedom to change policy, even without the shareholder approval required in $\S 13$ of the Investment Company Act of 1940, 54 Stat. 811, 15 U.S.C. \$ 80a-13 (1958) as a condition of change of fundamental policy. Whether a duty exists to do so would depend on many more factors than can be previsioned here.

42. See note 20 supra.

43. See note 29 supra and accompanying text. 
remiss for not substituting Gloria Gorgeous would not hesitate to point out that to denote a defendant as a director is but to begin an inquiry into his responsibilities in a particular case. If a bank depositor were suing a bank because its profits bore an unreasonably high relation to the interest it paid, the court would be equally quick to point out that denoting a defendant as a fiduciary merely initiates the inquiry into his specific responsibilities.

In the mutual fund situation failure to distinguish between mandated and unmandated responsibilities may result in vesting in directors a perennial (and potentially very costly) duty to review the total arrangement accepted by the shareholder when he purchased his shares-regardless of its reasonableness to or desirability for the shareholders as individuals and regardless of their acceptance of the arrangement with full disclosure thereof available to them. If every shareholder were a Mr. Smith, such a transfer of responsibility from fund shareholder to fund director would be shocking. Is it any less shocking because there is among shareholders a hypothetical Mr. Jones who did not avail himself of the information afforded? In this author's opinion, to key the law to Mr. Jones as against Mr. Smith is to rip out of the structure of our regulatory scheme its underpinning of disclosure and to confess defeat in the hard campaign against ignorance and cupidity and for the development of the mature investor.

But one need not reach so far to justify the allocation of responsibilities in the mutual fund-whatever its form and however one approaches it. Knowingly or otherwise, what the fund investor buys is an interest in a portfolio built by a specific management and supervised by it according to the stated policy and on specified terms of service. It is the materiality of these facts that endows their disclosure with materiality. The position Mr. Smith reached articulately Mr. Jones also occupies, even though he may not know how he got there. It is essential to the integrity of Mr. Jones' position, as it is to Mr. Smith's, that the clear division between mandated and unmandated responsibilities be recognized. If it is not, there is no conceptual warrant for not shifting to the fund management complex every responsibility (including that of revising investment objectives which may be vital to investors although technically not "fundamental")..$^{44}$ One might then legitimately ask not only what has happened to the elaborate structure of disclosure requirements applying to the fund institution as we have known it, but what has happened to the institution itself.

At stake in the basic conflict between the philosophies of disclosure and paternalism is more than a power struggle between elements of the fund. Disclosure, as a philosophy of regulation, not only emphasizes the in-

44. Under $\$ 13$ of the Investment Company Act of 1940 certain changes in funds cannot be made without approval of shareholders voting as a class, 54 Stat. 811 (1940), 15 U.S.C. $\$ 80 \mathrm{a}-13$ (1958). Among them is a change in "fundamental" policy. To be included in this ban, however, the policy must be stated in the fund's registration statement under the Investment Company Act to be "fundamental." Few funds "freeze" their traditional risk levels by stating them as fundamental. Ibid. 
vestor's responsibilities but creates both a means conducive to the best protection of the investor-self-protection through knowledge-and a public capable of demanding and through its patronage getting good value in its fund investments.

\section{The "Political" Aspect}

The burden on the investor to select carefully his fund investment exists in fact. No amount of intellectual manipulation can eradicate it. Once the investor makes his selection both law, as hitherto understood, and practice have combined to preserve its integrity. That he does not always choose the best fund, the best car, the best refrigerator or the best doctor should not condemn those who make and serve. It should prompt us to keep working at the hard task of informing and educating.

Attacks on advisory fees are often impelled by the raw feeling that somebody is making too much money and are justified by a dialectic designed to transform that feeling into law and practice via the courts. As we shall see, the drafters of the Investment Company Act thought deeply about many of the problems discussed here. The statute is carefully designed to preserve and enhance the service potentials of some aspects of the funds as the framers of the Act found them and to ban others. Various alternatives were considered and rejected by the drafters and Congress. For example, Section 205(1) of the Investment Advisers Act of 1940 outlaws fees which compensate the adviser "on the basis of a share of capital gains upon or capital appreciation of" a client's funds. ${ }^{45}$ One justification for this prohibition is that sharing in gains may stimulate flashy management which enriches the adviser on gains without taxing him for losses. ${ }^{46}$

Critics of advisory fees sometimes point out that times have changed since 1940 when the Investment Company Act was passed. The mutual fund is no longer a $\$ 450$ million segment of a total $\$ 1$ billion industry (open plus closed end investment companies) as it was then. The total industry has increased more than 20 fold since then, and the vast bulk of it is in mutual funds. ${ }^{47}$ By a rule of transformation of quantity into quality the mutual fund institution has, by this reasoning, been changed so that the practical wisdom

45. 54 Stat. 852,15 U.S.C. $\$ 80 \mathrm{~b}-5$ (1) (1958).

46. Even if the attack on fees in current litigation were to raise the problem of selecting positive alternatives to replace presently employed fee systems, under our governmental structure the legislature rather than the courts would seem the appropriate forum for effectuating a change.

... I suggest that the federal courts are not apt instruments either for national economic decisions, or for economic planning. They have neither mandate, method, nor competence to lay down the bases on which such decisions or such planning should proceed. Still less have they any business to assign themselves that function by their own fiat.

Berle, Legal Problems of Economic Power, 60 Coluar. L. Rev. 4, 7 (1960).

47. Source: National Association of Investment Companies. 
in its evolution and in the basic legal concepts applicable to it until now are no longer appropriate.

Intriguing as this reasoning is, it is misapplied here. The difference between a fender repair shop and General Motors is a vast difference in kind as well as degree. But the difference between a small fund and a large one is not. The large fund serves more people and, if it is economically run, enables its sponsors to earn more money. But the plant and equipment are still only tables, chairs and a library and the machine that produces the results is still only human brains. Its impact on our society is still primarily in terms of the spread of its service. As a storehouse of capital the modern mutual fund grows in size without introducing a new power pool into our society. Its sense of responsibility (neither greater nor less than that of the men who manage it) is inwardly oriented, toward its shareholders, not outward toward social power. 48

To summarize: a necessary preliminary step in appraising a fund shareholder's assertion of responsibilities in the mutual fund is to allocate those responsibilities. Behind any such allocation must lie a clear conception of what functions are and are not mandated by the shareholder. This conception must stem from the root ideas of fiduciary responsibility in our society. As do the other models, the fund model calls for a division between disclosed and accepted pre-existing "term of relationship" aspects of funds (which do not involve mandated responsibilities) and certain operational aspects of funds (which do involve mandated responsibilities). Thus one may rephrase the doctrine specifically for the mutual fund situation as follows: What the fund shareholder cannot do and cannot be expected to do or decide for himself is prima facie a mandated responsibility for breach of which liability may exist. What the fund shareholder can and should do for himself is prima facie an unmandated responsibility which does not create duties in others.

\section{The Impact of Statute}

So far we have but touched the threshold of the problem of directors' responsibilities; for while we have attempted to delineate broadly the areas in which a shareholder should or should not have standing to complain of alleged wrongs, we have not yet indicated when, if the claim can be heard, responsibility can be placed on the directors in addition to or to the exclusion of the adviser or others. And so far we have been deriving conclusions from the ethical underpinnings of the common law. How do the Investment Company Act of 1940 and related statutes affect these problems? Most relevant are the prospectus requirements of the Securities Act of $1933^{49}$ and the provisions

48. See Statement of Dorsey Richardson before the Senate Committee on Banking and Currency, March 16, 1955-available in pamphlet form from National Association of Investment Companies.

49. 48 Stat. 75, 15 U.S.C. $\$ 80 \mathrm{a}-2$ (a) (35) (1958), defining the term "prospectus"; Section 5(b), requiring the use of prospecti; 48 Stat. 81, 15 U.S.C. § 77(j) (1958) govern- 
of the Investment Company Act which require periodic reports, ${ }^{50}$ govern the affiliation of directors ${ }^{61}$ and subject both directors and advisers to prohibitions against double dealing, ${ }^{52}$ outright pilfering, ${ }^{53}$ or misconduct or abuse of trust generally. ${ }^{54}$ Also of crucial importance are the requirements of the Investment Company Act governing advisory contracts-both in terms of content and of the mechanics of adoption and renewal. ${ }^{55}$

\section{Disclosure Requirements}

Drafters of federal securities statutes had, and used, a vast array of legislative patterns ranging from disclosure to flat prohibition. ${ }^{56}$ The statutes applicable to mutual funds incorporate both patterns and a wide range in between. As perennial issuers of securities, funds are constant users of prospecti and are constantly subject to the requirement of the Securities Act of 1933 that the prospectus be, or that (with minor exceptions) it accompany, the first written offer of securities. ${ }^{57}$ The anti-fraud provisions of that Act ${ }^{58}$ and of the Securities Exchange Act of $1934^{59}$ are in effect controls over oral representations (as well as written ones) made in the offering of fund shares for sale. As we have noted, the Investment Company Act and rules thereunder provide for frequent periodic disclosure of progress to shareholders. ${ }^{80}$

As a philosophy of regulation, disclosure presupposes the materiality of the matters disclosed to the investor in the making of investment decisions. Except

ing the information required to be contained in the prospectus. See Investment Company Act of 1940, 54 Stat. 826 (1940), as amended, 68 Stat. 689 (1954), 15 U.S.C. \$ 80a-24(d) (1958) (removing fund securities from certain exemptions afforded by the Securities Act of 1933) ; SEC Reg. C, Art. 2, 16 C.F.R. $\S \S 230.420-230.431$ (1949) (covering form and content of prospecti generally).

50. 54 Stat. 836 (1940), 15 U.S.C. $\$ 80 a-29$ (d) (1958) requires transmittal to shareholders, at least semi-annually, of reports containing such information as the SEC shall prescribe. The rules are contained in Rules 30a-11 to 30f-3 of the General Rules and Regulations under the Investment Company Act. The SEC rules, 17 C.F.R. $\$ \S 270.30 \mathrm{a}-1$ to $270.30 \mathrm{f}$ -3 (1949) (with certain qualifications) incorporate the requirement of the statute itself that the following information be reported on: balance sheet, income, portfolio holdings, surplus, remuneration to directors, officers and any affiliate of a director (which may include the adviser), and amounts of purchases and sales of portfolio holdings.

51. 54 Stat. 806 (1940), 15 U.S.C. § 80a-10 (1958).

52. 54 Stat. 815 (1940), 15 U.S.C. \& 80a-17 (1958).

53. 54 Stat. 841 (1940), 15 U.S.C. \$ 80a-36 (1958).

54. 54 Stat. 841 (1940), 15 U.S.C. $\$ 80 a-35$ (1958).

55. 54 Stat. 812 (1940), 15 U.S.C. $\$ 80 \mathrm{a}-15$ (1958).

56. For an excellent short review of foreign and state precedents for federal securities legislation see McCormick, Understanding the Securities ACt and the SEC 3-18 (1940). More extensive is the discussion in Loss \& Cowetr, BLUE Sky LAw (1958).

57. See note 49 stipra.

58. Securities Act of $1933 \S \S 11,12,17,48$ Stat. 82,84 (1933), as amended, 15 U.S.C. $\S \S 77 \mathrm{k}, l, \mathrm{q}(1958)$.

59. Securities Exchange Act of $1934 \S \S 10$ and 15, 48 Stat. 891,895 (1934), as amended, 15 U.S.C. $\S \S 78 j, 78 o$ (c) (1958), and the rules of the SEC thereunder.

60. See note 20 supra and accompanying text. 
in rare instances, the act of disclosure forecloses any complaint about the matters disclosed. ${ }^{\text {11 }}$ Distinctions should, of course, be made between "fine print" spillage of complex language beyond the capacity of the normal investor to evaluate, and disclosures which are plain, obvious, and at the heart of the relationship to be established. One of the constant endeavors of the Securities and Exchange Commission in administration of disclosure requirements has been to make disclosures plain and meaningful. ${ }^{62}$ Anyone who has compared a typical corporate prospectus with those used by mutual funds will recognize that the latter have come close to achieving this result. One cannot read a mutual fund prospectus, even hastily, without comprehending the essential facts about the fund, its adviser, and the adviser's relation to the fund. ${ }^{83}$

For protection against abuse in the operation of a fund, the investor must look to others to carry out their responsibilities. In recognition of that fact the Investment Company Act includes mutual fund officers, directors, advisers and principal underwriters within the class of persons who may be enjoined by the Securities and Exchange Commission from "gross misconduct" or "gross abuse of trust." 44 It makes theft, embezzlements or conversions by anyone unlawful, ${ }^{65}$ outlaws double-dealing by insiders, ${ }^{60}$ and bans certain exculpatory protections of directors and advisers. ${ }^{67}$ Finally it requires responsible custodianship of assets, ${ }^{68}$ appropriate bonding of persons in certain sensitive jobs, ${ }^{69}$ and the exclusion of people with violation records from others, ${ }^{70}$

61. One of the notable instances is $\S 16$ (a) of the Securities Exchange Act, 48 Stat. 896 (1934), 15 U.S.C. $\$ 78 \mathrm{p}$ (a) (1958), which requires disclosure of changes in equity holdings by corporate insiders. Section 16(b), 48 Stat. 896 (1934), 15 U.S.C. $\$ 78 p(b)$ (1958), creates a civil liability for the return of profits made by insiders in certain shortswing transactions. One of the purposes of requiring disclosure is, of course, to enable suits to be brought under $\S 16(\mathrm{~b})$. Disclosure under $\S 16(\mathrm{a})$ does not immunize from suit under $\$ 16(\mathrm{~b})$.

62. See MCCoRMICK, op. cit. supra note 56, at $152-59$.

63. For example, the prospectus of Fundamental Investors, Inc. (April, 1960 ed.) devotes more text space to a description of the adviser, Investors Management Company, Inc., than to any other aspect of the Fund. The personnel, functions, advisory agreement, the advisory fee, directors and technical consultants are described.

64. Investment Company Act of $1940 \S 36,54$ Stat. 841 (1940), 15 U.S.C. § 80a-35 (1958).

65. Investment Company Act of 1940 § 37, 54 Stat. 841 (1940), 15 U.S.C. $\S 80$ a-36 (1958).

66. Investment Company Act of $1940 \S \S 17(\mathrm{a}),(\mathrm{d}),(\mathrm{e}), 54$ Stat. 815, 816 (1940), 15. U.S.C. $\S \S 80 \mathrm{a}-17$ (a), (d), (e) (1958).

67. Investment Company Act of $1940 \S 17(\mathrm{~h}), 54$ Stat. 817 (1940), 15 U.S.C. $\S 80 \mathrm{a}-$ 17.(h) (1958).

68. Investment Company Act of 1940 \& 17(f), 54 Stat. 816 (1940), 15 U.S.C. § 80a$17(\mathrm{f})(1958)$.

69. Investment Company Act of $1940 \S 17(\mathrm{~g}), 54$ Stat. 816 (1940), 15 U.S.C. $\S 80 a-$ $17(\mathrm{~g})(1958)$.

70. Investment Company Act of $1940 \S 9,54$ Stat. 805 (1940), 15 U.S.C. $\S 80 \mathrm{a}-9$ (1958). 
and provides that Commission approval must be sought before many important transactions likely to affect shareholders may be effectuated. ${ }^{71}$

For protection against terms that he may deem unsuited to his needs or onerous, the investor must look to himself, aided by the information supplied in the prospectus or other disclosures. The statutory pattern, in this sense, assumes that the investor has, and should be given the opportunity to exercise intelligently, the responsibility of choosing his fund investment, ${ }^{72}$ and recognizes the existence of two separate areas of responsibility - that of the investor to use the information supplied and that of the fund management to supply the information and to live up to the expectations reasonably aroused by the information. Indeed some of the largest houses distributing mutual fund shares through so-called "contractual" plans voluntarily exceed the statutory requirements of disclosure-requiring the investor to apply for his plan on a form which sharply discloses elements of shareholder cost, sending him a duplicate copy of his signed form, and telling him that he may, within thirty days, receive a refund of his investment if the plan is not in accordance with his understanding. ${ }^{73}$

\section{The Statutory Allocation of Functions and Duties}

This pattern of division of responsibilities seems, so far, clearly envisioned in the statute. But there are two elements of the Investment Company Act which must be carefully inspected to see whether they change the pattern and, if they do, to what extent. These critical elements are functions vested by the Act in directors respecting the advisory contract and catch-all provisions of the Act designed to prevent abuse of trust.

a. Directors' functions respecting the advisory contract:

Under the Act no adviser may serve a fund except pursuant to written contract. ${ }^{74}$ Every contract, or such change therein as creates a new contract, must be approved by vote of the holders of a majority of outstanding fund shares. ${ }^{75}$ No contract may last more than two years unless renewed at least annually by shareholders as a class or by the directors, including a majority

71. See, e.g., Investment Company Act of $1940 § 25,54$ Stat. 826 (1940), 15 U.S.C. $\S 80 \mathrm{a}-25$ (1958).

72. See MCCorMITCK, op. cit. supra nate 56 , at 152.

73. See Association of Mutual Fund Plan Sponsors, "The Origin and History of the Contractual Plan," p. 16 (1960). An interesting reflection on this withdrawal privilege is the fate of a proposal of the SEC staff more than a decade ago to amend the Securities Act of 1933 to give the purchaser of newly underwritten corporate securities forty-eight hours in which to withdraw after having the prospectus made available to him. Representatives of the investment banking industry resisted this interruption in the normal flow of commitments and the proposal was never adopted. See discussion of the "out" clause in Lobell, Revision of the Securities Act, 48 Conun. L. Rev. 313, 331-32 (1948).

74. See note 27 supra.

75. Investment Company Act of 1940, 54 Stat. 812 (1940), 15 U.S.C. $\S 80 a-15$ (a) (1958). The requirement of shareholder approval of contract changes is a derivative of the broad requirement of $\$ 15$ (a) that the "contract" be "approved by the vote of a majority of the outstanding voting securities." 
of directors having no affiliation with the adviser. ${ }^{76}$ An assignment of the advisory contract by the adviser voids the contract. ${ }^{77}$ Shareholders as a class, or directors, may at any time cancel a contract on 60 days notice and without penalty. ${ }^{78}$ Directors may recommend a substitute adviser for one serving the fund, but they cannot approve a substitute. The approval of a substitute is a matter exclusively within the purview of shareholders acting as a class. ${ }^{79}$ Directors may recommend a change in the fee or in any other term of the contract. But these, too, cannot be adopted without approval of shareholders acting as a class.

The statute, it should be observed, departs from the typical corporate model in these prescriptions. Directors of a typical corporation are not only permitted but are expected to use their own judgment and discretion in hiring, firing and compensating management personnel. In the mutual fund, however, the statute creates a unique division of hiring, firing and compensation responsibilities 1) by permitting directors to fire an adviser without referral to shareholders, but requiring shareholder approval of any replacement; and 2) by requiring shareholder approval of any fee or any change in the fee.

The apparent oddity of this scheme disappears when we view it in the light of the doctrine of mandated responsibilities as applied to the mutual fund situation. If an adviser is creating an urgent possibility of critical damage to the fund, the directors may need the power of cancellation. However, the statute, through this scheme of severing from directors functions normally vested in them, through provisions giving a strong position to the adviser on the board of the fund, ${ }^{80}$ through provisions against assignment of advisory contracts, ${ }^{81}$ and through the requirements of disclosure about the adviser, recognizes the close link between the adviser and the shareholder, the signifcance of the adviser's identity in the shareholder's choice of the fund shares and the reliance of the shareholder on the adviser for the essential function of investment management. ${ }^{82}$ It should not be considered as strange, therefore,

76. Investment Company Act of $1940 \S \S 15(\mathrm{a})(2), 15(\mathrm{c}), 54$ Stat. 812 (1940), 15 U.S.C. $\$ \S 80 \mathrm{a}-15$ (a) (2), -15 (c) (1958).

77. Investment Company Act of $1940 \S 15$ (a) (4), 54 Stat. 812 (1940), 15 U.S.C. $\S 80 \mathrm{a}-15$ (a) (4) (1958). For a discussion of some of the implications of this requirement see Lobell at n.58, and 212 .

78. Investment Company Act of $1940 \S 15$ (a) (3), 54 Stat. 812 (1940), 15 U.S.C. $\$ 80 a-15$ (a) (3) (1958).

79. This, too, is a derivative of the requirement of $\S 15$ (a) that no adviser may serve, except under a contract approved by holders of a majority of voting shares.

: 80. . Investment Company Act of 1940 § 10, 54 Stat. 806 (1940), 15 U.S.C. § 80a-10 (1958). In effect this section permits the adviser to be represented by at least 4 and as many as 9 affiliates on the fund board of ten members. See Lobell at 207-11.

81. Investment Company Act of 1940 \& 15(a) (4), 54 Stat. 812 (1940), 15 U.S.C. $\S 80 \mathrm{a}-15$ (a) (4) (1958).

82. See testimony of David Schenker, counsel to SEC's Investment Trust Study. In referring to the change made in the original bill (so as to allow a majority of boards in certain cases to contain a majority affiliated with the adviser), Mr. Schenker stated:

The bill as originally introduced had a different provision. It required that a majority of the board be independent of the management. However, the argument was made 
that the statute retains for the shareholders, as distinguished from the directors, the dispositive function of approving or disapproving the selection of an investment adviser and of the terms of his service. ${ }^{83}$

This is a key fact about the Act, and typical of the approach and aim of its drafters. While they could not, in prescribing standards, be wholly indifferent to the legal form assumed by the fund, ${ }^{84}$ the drafters came as close to that approach as possible. Their conceptual model was neither the corporate stereotype on the one hand nor the business trust on the other (these being the principle forms assumed by funds) but a relation of stewardship whose attributes were to be preserved whatever form the fund took. The prime factors in the stewardship, as the drafters conceived it, were the investor and the adviser. If a fund was in trust form without a board of trustees (or "directors" within the meaning of the statute), it was not required to change its structure to include such a board. In this type of fund the relation between shareholder and adviser remains, in structure as well as in intent, direct and unmediated by a board of any kind.

It is against this background that the functions of the board of directors with respect to the adviser must be viewed. Under the statute the board has the option of passing on annual advisory contract renewals or of remitting the question to shareholders as a class. They, as well as the shareholders as a class, have the power to initiate a cancellation of the contract at any time on

that it is difficult for a person or firm to undertake the management of an investment company, give advice, when the majority of the board may repudiate that advice. It was urged that if a person is buying management of a particular person and if the majority of the board may repudiate his advice, then, in effect, you are depriving the stockholders of that person's advice. Now that made sense to us. If the stockholders want A's management, then A should have the right to impose his investment advice on that company.

Hearings on H.R. 10065 Before a Subcommittee of the Committee on Interstate and Foreign Commerce, 76th Cong., 3d Sess. (1940).

83. The power of shareholders, as a class, to approve or disapprove an adviser is in addition to their power as individuals to accept or reject the adviser's service both in their original consideration whether or not to purchase the fund's shares and in their exercise or failure to exercise their rights of redemption. A shareholder, who of course accepted the shares originally, is free to vote against the adviser. Barring material changes in circumstance such adverse votes are likely to be, and have in fact been, small in numbereven in the face of opposition to the adviser. A recent shareholder proposal to cancel an investment advisory contract of a fund received 7 million favorable votes out of 111 million shares voting. See Wall Street Journal, April 6; 1961; p. 2.

84. Special provisions of $\S 16(\mathrm{~b})$ making exceptions to the usual proxy and voting procedure for funds in trust form in existence prior to 1940 were urged on the Congress in part because of the possibility that under the laws of certain states, shareholders of fund trusts, with voting power, might be liable for debts incurred by the trustee in his official capacity. Hearings on S. 3580, part 2, Before a Subcommittee of the Senate Committee on Banking and Currency, 76th Cong., 3d Sess. 590-95 (1940).

See also $\S 15(c)$, which provides for approval of advisory and underwriting contracts by unaffiliated directors only in funds "having a board of directors." Investment Company Act of 1940, 54 Stat. 812 (1940), 15 U.S.C. $\$ 80 \mathrm{a}-15$ (c) (1958). 
60 days notice. However, the statute does not state what occasions are and are not proper for a veto or cancellation by directors. Those standards must be derived from other provisions of the Act and relevant law and must be consistent with the Act's general pattern and purpose. To be indifferent to either, in filling the gap, may lead one into the error of reshaping the hole in a jigsaw puzzle to accommodate a foreign piece.

Certain occasions for a veto or termination are obvious. Dishonesty of the adviser, his rank departure from risk levels associated with the fund's traditional policy, his failure to maintain a level of professional competence in fund management-malpractice in carrying out any of the vital functions falling within the scope of mandated responsibilities, would under any circumstances, with or without statute, seem to justify contract termination. These are functions which the shareholder cannot himself oversee; they are peculiar to the internal, operational aspects of fund management. An adviser who is guilty of malpractice in carrying out these functions belies the legitimate expectations and understandings motivating investors to entrust their money in the fund. Such practices are, in a real sense, a failure of the trust through acts which the shareholder cannot himself detect until after the harm is done. To oversee the operations of the fund for the purpose of detecting and stopping such practices is clearly within the scope of mandated responsibilities of directors and, in appropriate cases, one has no difficulty in concluding that liabilities may follow.

Does the Act, however, create an obligation in directors to terminate contracts on grounds which are not mandated responsibilities? Suppose, in the judgment of directors a fund is losing possibilities of gain in a rising market by maintaining its practice of investing only in common stocks of established companies rather than in more speculative issues, and the directors urge the adviser to adopt a change which, though not "fundamental" within the meaning of Section 13 of the Act (requiring approval of shareholders), would materially change the risk level traditionally associated with the fund. Are they warranted in vetoing or cancelling the contract because of this type of difference of opinion with the adviser? One would think not. The risk level associated with the fund (whether or not part of the fund's "fundamental" policy as defined by statute) was apparent to investors in their original selection of the fund's shares. The fund they chose was managed by an adviser who operated according to that policy; no critical problem of conserving assets in the face of imminent danger is presented; and to assume even freedom (much less responsibility) in the directors to fire the adviser because he insists on continuing with the policy would be to assume that directors may remake the essential aspects of the arrangement the shareholder thought he was making when he bought the fund shares.

Suppose that directors have no difference of judgment with the adviser as to any aspect of the advisers' operations but are offered the services of another adviser willing to work for a lower fee. Are they free, on the ground of the 
rate of the fee alone, to fire the adviser? Are they responsible if they do not? Are they obligated affirmatively to dicker with an adviser over his fee, and, if the dicker fails, to fire him? To vest responsibility for these functions in directors again implies that directors are not only free but obligated to remake the arrangement the shareholder thought he was making when he bought the fund shares. A director might conceivably assume that investment management skill is a fungible commodity, that one adviser is as good as another, and the cheaper the better. But investors are not presumed to feel that way. As we have noted, the law prescribes requirements of disclosure, and mechanics of advisory contract approval-giving only shareholders the power to approve the selection of an adviser and the fixing of his fee-which make no sense unless the responsibility of the investor in the choice of his adviser and of the adviser's terms of service were deemed to be one of the prime elements in his choice of the fund.

Dicta at variance with this view are expressed in Brown v. Bullock. ${ }^{85}$ Since it is the first decision dealing with issues being raised in many similar cases, ${ }^{80}$ and formulates at length the basis for its conclusions, the language of the opinion as well as the narrow issues decided merit extended comment. It should be noted at the outset that the court in the Brown case was passing on a motion to dismiss a complaint-and not on the merits. Further, the court dealt with the issues as posed, and these did not include the notions of division of responsibility here discussed or of the unique nature of the fund or the unique provisions of statute as they bear on the division of responsibilities.

The Brown case was a mutual fund shareholders' action naming as defendants the adviser and directors of the fund. The complaint alleged that the adviser (who is also principal underwriter) dominated the unaffiliated directors of the fund; that the advisory fee was exorbitant; $; 7$ that the sales charge was exorbitant; that both the advisory fee and sales charge were harmful to the fund, were a waste and spoliation of fund assets and constituted wilful conversion and gross negligence and abuse of trust. In addition, it was alleged that proxy statements used to solicit votes for the election of directors were false in that they failed to reveal that the adviser had other funds under management at fee rates lower than those fixed by contract with the instant fund. In all, violations of eight sections of the Investment Company Act were alleged. 88

85. Civil No. 60-3106, S.D.N.Y., March 9, 1961.

86. See note 2 sutpra.

87. The advisory fee involved in Brown v. Bullock was $1 / 2$ of $1 \%$ of assets up to $\$ 100$ million and $1 / 4$ of $1 \%$ on all thereafter. Since the Fund's assets stood at close to $\$ 300$ million, the overall fee was roughly $3 / 10$ of $1 \%$. As we have observed in the majority of funds, the fee is $1 / 2$ of $1 \%$. See note 37 supra.

88. These included: $\$ 15$ (a) (3), providing for cancellation of advisory contracts on 60 days notice, 54 Stat. $\$ 12$ (1940), 15 U.S.C. $\$ 80 \mathrm{a}-15$ (a) (3) (1958); $\$ 17(\mathrm{~h})$, barring clauses exculpating directors from "willful misfeasance, bad faith, gross negligence or reckless disregard" of duties, 54 Stat. $\$ 15$ (1940), 15 U.S.C. $\$ 80 a-17(h)$ (1958); § 17(i) 
Defendants moved to dismiss on grounds that statutory violations do not give rise to private causes of action under the Investment Company Act and that even if they did, no causes of action were alleged because the conduct alleged did not constitute violations. The motion was denied. Beyond several references to the possibilities of management abuse inherent in funds the opinion is devoid of any discussion of the unique character of the fund. The function of the mutual fund, as a vehicle for rendering investment advisory services, was neither considered nor evaluated in the court's interpretation of the law and its objectives. The conceptual model presupposed in the court's opinion was apparently the typical corporate model, assuming responsibility in the director to terminate or veto a contract on any ground on which one may make a judgment with respect to the contract, including the compensation involved, and ignoring the question whether some of these judgments might not be exclusively within the purview of shareholders rather than of directors.

The opinion illustrates a high sensitivity to the fiduciary nature of fund management responsibilities and an extreme reluctance to interpret the Act in any but the broadest possible terms-presumably for fear that any narrowing of interpretation might leave chinks in the structure through which unknown dangers might slip. ${ }^{89}$

Noting that the Investment Company Act gives directors the power to veto a contract renewal or to cancel it on notice, the Court said:

The directors are thus charged by the Act with critically important powers and duties of a specific nature. ... The grant of these defined 90 powers, as specified in the Act, carries with it the duty to determine whether or not the extension is desirable and in the best interest of the company. The power to terminate the investment advisory contract necessarily carries with it the duty to keep alert for reasons which might make

providing similar bars for advisers and underwriters, 54 Stat. 815 (1940), 15 U.S.C. \& 80a17(i) (1958); § 20(a) making it unlawful to solicit proxies in violation of SEC rules, 54 Stat. 822 (1940), 15 U.S.C. \$ 80a-20(a) (1958); \& 34(b) making it unlawful to file false reports, 54 Stat. 840 (1940), 15 U.S.C. \& 80a-33(b) (1958); \& 36, giving SEC power to seek injunctions against gross misconduct and gross abuse of trust, 54 Stat. 841 (1940), 15 U.S.C. $\$ 80 \mathrm{a}-35$ (1958); $\$ 37$, outlawing wilful conversion and other crimes of abstracting property, 54 Stat. 841 (1940), 15 U.S.C. $\S 80 \mathrm{a}-36$ (1958); \& 44, giving courts jurisdiction of suits, 54 Stat. 844 (1940), 15 U.S.C. $\$ 80 \mathrm{a}-43$ (1958) and $\S 47$ (b) voiding contracts in violation of the Act, 54 Stat. 846 (1940), 15 U.S.C. $\$ 80 a-46(b)$ (1958).

The court, finding the complaint sufficient in its allegations of a violation of $\$ 37$ arising out of the advisory fee, did not pass on the question of the sales charge. Civil No. 60-3106, S.D.N.Y., March 9, 1961, pp. 36-37.

89. Hence statements expressing fear of "emasculating" the Act, the search for fiduciary standards in the Act "regardless of their foundation in the common law," the reference to the "law-enforcement" aspects of private litigation based on statutory violations in the "light of the distinctive character of investment companies and their easy susceptibility to management abuses . . both crude and subtle." Civil No. 60-3106, S.D.N.Y., March 9, 1961, pp. 53, 37, 43.

90. The court does not mean the word "defined" here to signify that the Act "defines" the occasions for exercise of directors' power of veto or termination. It is the absence of such definition which gives rise to the problem of interpretation. 
termination necessary or desirable; and, in the presence of such reasons, to exercise the right of termination. The objectives of the Act would be nullified if the directors were free to extend mechanically the contract without honestly exercising their best judgment. The objectives of the Act would be equally frustrated if the directors were free to close their eyes to any developments making the termination of the contract advisable. ${ }^{91}$

Into the gap left by the Act (in its failure to specify the occasions for a director's veto or cancellation of a contract) the court infuses the broadest possible range of standards. Directors must affirmatively decide that the contract is "desirable" and "in the best interest of the company." In an "honest" exercise of their "best judgment" they must be alert "for reasons making a termination necessary or desirable."

Were the complaint one which alleged facts bearing on breaches of responsibility that could reasonably be allocated to any section of the fund management complex the courts' language, though broad, would be apt. However, behind the conclusory allegations of the complaint is the simple claim that the advisory fee is too high. If the plaintiff were a client of a private adviser making a similar complaint against the adviser, the court would presumably make short shrift of it. Having accepted the terms of the adviser's service, the investor either pays the fee or withdraws his account. The court will not reform his arrangement for him-although it will be vigilant to undo any harm done by the adviser in failing to carry through a mandated responsibility. ${ }^{93}$ And, further, none of the court's language referring to directors could have any application to a case involving a mutual fund which is not a corporation and has no board of directors or trustees.

Thus, if one works toward the fund from the conceptual model of the private client-counsellor relationship, through the model of a fund without a board, logic compels one to ask why the existence of a board of directors should transform a clear investor responsibility (to accept or reject the terms of service) into a directors' responsibility (to remake the terms of service).

91. Civil No. 60-3106, S.D.N.Y., March 9, 1961.

92. The very use of the term "company" in this context reveals the court's carry over, to this special field, of concepts from the general storehouse of corporate analogies. The "best interests of the company" are irrelevant to the best interests of fund shareholders, if the "company" be assumed to have any existence apart from the cluster of relations inherent in it. A fund growing in size is not necessarily increasing shareholders' asset value. A conservative fund may not be making as much profit as a speculative one. The "best" judgment of directors may dictate that it would be "desirable" to change the risk level of the fund-but that judgment would be irrelevant to either their freedom or responsibility to remake the fund into something other than what shareholders believed they were purchasing. That courts are led into error of this kind by reasoning like that in Brown v. Bullock is obvious from Taussig v. Wellington Fund, Inc., 187 F. Supp. 179 (D. Del. 1960). See Lobell 181, 192-96.

93. See Aldred Inv. Trust v. SEC, 151 F.2d 254 (1st Cir. 1945), cert. denied, 326 U.S. 795 (1946) ; Greene, Fiduciary Standards of Conduct under the Investment Company Act of 1940, 28 GEO. WASH. L. REv. 266, 272-81 (1959). 
Unless specifically compelled by statute to do so, to hinge consequences on the existence or nonexistence of a board is to lose touch both with the purpose and pattern of the statute and with the ethical predicates which we have here explored. The court, however, did not work up from the client-counsellor model (which is in fact the anchor of the fund in its tradition of stewardship) but worked down from the typical corporate model. In doing so, it ignored the pointed indications in common understanding and in the Act and its legislative history that the adviser, his fee, and his policy are terms of the fund relationship accepted by the investor and that, however broadly one may construe the responsibilities of directors as overseers of the fund's operations, those responsibilities do not embrace a duty in the director to substitute himself for the shareholder in matters of judgment crucial to the shareholder in his original determination whether or not to accept the adviser and the terms of his service.

One feels that the court was asking: "If the directors are not responsible for independent judgment in reviewing every aspect of an advisory contract, including the fee, who is?" The court's analysis does not recognize a division of responsibility between shareholder and director. Without a sufficient dialectic based on the nature of Mr. Smith's relations with his adviser through the fund, or a view of the Act as a whole and its intention to legislate in the light of those relations, the court's reluctance to draw any line of division in responsibilities was understandable. In doing so, however, it gave Mr. Smith a windfall which neither he nor those responsible for his protection anticipated. It freed him from his own bargain by vesting in others the duty of remaking that bargain for him. Mr. Smith may well pause before picking up this windfall. For he runs the danger that if his bargain may be remade to lower the fee he accepted, it might also be remade to change other terms of his arrangement in a manner or for a purpose he may regard as onerous or unsuited to himself..$^{94}$

A more recent related decision-that of Delaware Chancellor Seitz in Meiselman v. Eberstadt ${ }^{95}$ _dealt with a complaint in substance similar to that in the Brown case and dismissed the complaint on the merits after trial. Plaintiffs made the interesting assertion that the compensation of a fund officer or director affiliated with the adviser is to be measured by his personal share in the advisers' revenues and contended that the compensation, so measured, was excessive in the particular case. The Chancellor refused to find the compensation excessive, although he thought it on the high side as compared with that of other fund executives. He gave great weight to the fact that unaffiliated directors had annually approved the fee (which, like that in the Brown case, was lower than the average for mutual funds) and that within recent years shareholders as a class had done so. The provisions of the Investment Company Act were neither pleaded nor dealt with in the opinion. The unique

94. See Lobell 192-96.

95. 170 A.2d 720 (Del. 1961). 
nature of the fund, the division of responsibilities in the fund, and the impact of the Investment Company Act were neither argued nor decided.

These issues, though not packaged for decision by counsel, were nevertheless inherent in the Chancellor's reasoning-which hinged on the premise that fiduciaries "of course, may not pay themselves excessive compensation." While thoroughly applicable as a basis of judicial scrutiny of fees of guardians, testamentary trustees, receivers and others similarly imposed on the cestuis, there is considerable question whether the doctrine is equally applicable to fund advisers in the context of disclosure and of the unique nature and structure of funds. The formula urged by plaintiff and not attacked by defendantsthat of stepping over a fee competitively appealing to and accepted by thousands of investors to get to the shares in the advisory company's revenues of individual officers and directors of the fund-seems in itself to be a fluctuating benchmark, one that may depend on the accidents of distribution of ownership within the advisory company. In the Meiselman case, however, it was a natural corollary of the unexplored premise of the case: that no consideration is to be given to the role of the investor in deciding whether or not to accept the adviser at his disclosed terms. This is a characteristic of all the cases discussed in this article, one that stems from the approach of counsel themselves to the fund institution.

b. Catch-all provisions of the Act:

We have thus far not commented on two key provisions of the Investment Company Act: Section 36 which empowers the SEC to seek injunctions against "gross misconduct" and "gross abuse of trust" by fund directors and advisers, and Section 37 which makes it a crime to steal, unlawfully abstract, unlawfully and wilfully convert, or embezzle fund assets.

It has hitherto been assumed that both these sections are funnels, means of infusing into the statute the judge-made precedents we call "common law" to cover wider ranges of duties than a statute could conveniently list individually. ${ }^{96}$ There is ground for believing that they will now be regarded as general rubrics, embodying not only the common law prescriptions but those which can be fairly derived from other and more specific sections of the Act. ${ }^{97}$

However one reads them, these sections do not, by themselves, specify precise standards of conduct in precise situations. Regarded as conduits of the

96. See Greene, supra note 93, at 269-72. The same reasoning applies to $\$ \$ 17(\mathrm{~h})$ and (j) which ban clauses exculpating officers, directors and advisers from liability by reason of "willful misfeasance, bad faith, gross negligence, or- reckless disregard of the duties involved in the conduct of office." Investment Company Act of 1940, 54 Stat. 817, 15 U.S.C. $\S \S 80 \mathrm{a}-17(\mathrm{~h})$ \& (j) (1958).

97. This is the minimal interpretation that can be given to the court's statement in Brozen v. Bullock that

The federal sanctions were not placed in ... section 36 for the sole purpose of enforcing exclusively State-created duties as prescribed and defined in multitudinous State corporation laws and their interpretive decisions. The more reasonable view is that the main purpose for placing these elaborate and detailed federal sanctions in 
common law they remit one, as any general statement of fiduciary obligation does, to a closer inspection of the claims asserted in the light of the sense of the law, to determine whether the claim is enforceable. The claim that a fee is exorbitant has little merit when asserted by a shareholder who accepted the same fee when he bought his shares originally and alleges no grounds for concluding that the fee is any more onerous to him now than it was then. Regarded as repetitive of other and more specific statutory requirements, these sections remit us back to a statute which neither in terms nor in discernable intention places a responsibility on anyone but the investor to decide whether an advisory fee should be paid. ${ }^{98}$

Thus, again, to predicate a liability under Section 37 or 36 remits one to the sources of fiduciary obligation to find whether an alleged "conversion" or "gross abuse" is founded on any conduct which could constitute violation of duty.

How did the court approach this problem in Brown v. Bullock? In urging dismissal of the complaint defendants argued that the Investment Company Act does not regulate fees and that therefore no cause of action based on a complaint about fees can be grounded on an alleged violation of the Act. The court dismissed this argument as "beside the point" and said:

The absence of mechanical statutory limits for the fees or commission does not prevent the application of Section 37 once its factual prerequisites are shown to exist. The size of the payments received by defendants is only an evidentiary, not an operative fact. The size of the payments considered together with other material and evidentiary circumstances (such as the use of false and misleading statements, collusion, the relationship of the size of payments to the value of the services allegedly rendered) may establish the ultimate fact of deliberate appropriations and the conclusion of willful conversion. ${ }^{89}$

The pleading which, according to the court, sufficiently alleged the "factual prerequisites" of an inquiry into the "other material and evidentiary circumstances" was a set of conclusory allegations to the effect that the fee was

this regulatory Act was to enforce compliance with the Act and the performance of the duties imposed by the Act.

Civil No. 60-3106, S.D.N.Y., March 9, 1961, p. 53 (emphasis supplied).

In a note to this statement the court says, in apparent second-thought, that "section 36 was a reservoir of fiduciary obligations imposed on affiliated persons to prevent gross misconduct or gross abuse of trust not otherwise specifically dealt with in the Act." Id. at 54.

One senses in the court's first statement above that it was perhaps reaching for a "code" self-contained in the Investment Company Act warranting a new departure in basic fiduciary doctrine. This is reinforced by the court's reference to fiduciary standards in the Act "regardless of their foundation in the common law."

98. We feel that [the level of the advisory fee] is a question for stockholders to decide. If they want to pay a man a million dollars to manage the fund and if they know they are paying him a million dollars ... this bill says that is perfectly all right. Testimony of David Schenker, Senate Hearings on S. 3580, supra note 84, at 252.

99. Civil No. 60-3106, S.D.N.Y., March 9, 1961. 
exorbitant, the directors were dominated by the adviser and that the sum of their delinquency was a wilful conversion and gross abuse of trust. We are not concerned here with the court's view of what constitutes good federal pleading, but with some of the consequences of holding that this type of pleading may provoke a court's inquiry into the other "material and evidentiary" circumstances. Although incidental to the main theme of this article, these circumstances bear discussion.

1. False and Misleading Statements. The complaint alleged that proxy statements used in the solicitation of votes for directors were false and misleading. These allegations were particularized to complain that while the proxy statement stated the adviser's contract with the fund to be "similar" to other contracts between the adviser and the other funds, it was not disclosed that the adviser was serving other funds than the instant one at lower aggregate fees. To hold this "failure of disclosure" material is to assume the answer to the main question of the case. How much the adviser charges in the management of other funds is relevant to the question whether a director is or is not qualified for office only if one assumes a legal obligation in the director to get the lowest possible fee. ${ }^{100}$ However, "no fund director (or any other director) can be expected to buy cheaper that which only experience can show to have been bought well at any price."101

2. Lack of Independence. Whether or not a director is independent is an important fact about him. But whether an alleged lack of independence can ground a complaint depends on whether one can trace a justifiable wrong to the lack of independence. There is no doubt, for example, that a shareholder may not be heard to complain that a director failed to fire an adviser of a bond fund because more money could have been made by converting it into a stock fund. Nor could such a complaint be made legally sufficient by alleging that the director who failed in his alleged duty to fire the adviser did so

100. It is at this point that most lawyers pause-for the text seems to assume that there are no conditions in which the size of a fee can give rise to a problem for directors. This is not so. A fee rate may be so high as to make it doubtful that the fund could achieve its investment objectives. If so, the fee is a built-in aspect of the fund that frustrates the very purpose of the trust. An adviser or a director taking a position in such a fund, or a director of a fund whose adviser is demanding an increase in fee to such a level runs the risk of being charged with participating in a venture so hopeless as to be beyond legitimization by disclosure-for ipso facto only those unable to protect themselves in entry into a contractual arrangement would purchase or retain the shares. The prevailing range of advisory fees in mutual funds is not an arbitrarily determined one. Its extremes of high and low are set to fix a range in which fund management costs are reasonably related to possible investment results, and are substantially lower than costs in other types of portfolio management. A court faced with pleading like that in Brown v. Bullock could insist on particularization which will tell it what the fee in the particular case is and where it falls within the prevalent range of fees. If it chooses not to make this a matter of pleading, it may take judicial notice of the same facts. What the prevailing range of fees is, where the fee in any fund before the court falls within the range are matters widely published, and indisputable-and would, therefore, seem to be proper matters for judicial notice.

101. Lobell 207. 
because he was beholden to the adviser. Thus, the "evidentiary circumstance" of lack of independence in directors is not material unless it results in acts which, for other legal reasons, can properly ground a complaint. To treat it otherwise is to endow it with qualities of self-levitation.

3. The Worth of the Services. Among the "related evidentiary circumstances" which the court considered material to an inquiry into "willfull conversion" is "the relationship of the size of payments to the value of the services allegedly rendered." This parenthetical remark of the court is potentially the most far reaching element of its opinion. It may be taken for granted, in view of the court's rulings on the pleading in Brown v. Bullock, that every complaint that comes before it will contain the verbal formula which the court has deemed adequate to stand against a motion to dismiss. Thus every case might be postured so as to make the court an agency of review of the worth of advisory services in mutual funds.

This is an awesome task for any court to assume (even if it were to be granted that it is at all a matter of judicial concern). No plaintiff need ever fear that a court will raise an advisory fee. It is for the defendant to fear that any fee, no matter how low, may involve him in charges of wilful conversion which will subject the fee to judicial scrutiny beyond that of the market place and of the investors' acceptance..$^{102}$

Of some 250 mutual funds in existence there are very few that do not have advisory contracts with an advisory house. The rest operate under advisory

102. It is to avoid just this sort of danger that courts have often insisted that

The dissenting shareholder should ... have more than a claim based on mere differences of opinion upon the question whether equal services could have been secured for somewhat less.

Seitz v. Union Brass \& Metal Mfg. Co., 152 Minn. 460, 464-65, 189 N.W. 586, 588 (1922).

Directors could refuse to pass on contract renewals and remit this question, as they may under $\S 15$, to the shareholders of the fund. This affords a dubious protection under the broad language of Brown v. Bullock. For the assent of the shareholder to a fee expressed in his initial purchase of the shares did not, according to the opinion, immunize directors from responsibility for reviewing the fee to determine whether to cancel the contract on 60 days notice. And, in addition, the opinion holds the complaint sufficient even though it alleges no material changes in circumstances since plaintiffs' acquisition of their shares. Directors could insist on competitive bidding for fund advisory contracts. But they run the danger of being deemed insurers of any cheaper replacement they recommend solely because it is cheaper. And if the replacement adviser still manages to make a profit at the lower fee, the profit is a danger to directors; for any profit can be cut. Further, since only shareholders as a class can approve a replacement adviser, every attempt of directors to replace an adviser is an occasion for proxy solicitation and an invitation to proxy warfare with the traditional adviser anxious to maintain his traditional relationship with the fund. The absurd result is, as the author has previously noted, to resubmit to shareholders who chose the adviser originally in their purchase of shares the question whether the adviser should continue to serve (whether or not there have been any material changes in circumstances) and, ironically, to face the very high probability that the traditional adviser will keep that position. Thus, through wasteful, expensive and fund shattering warfare, the directors, to fulfill imputed obligations, will have taken steps which bring them full circle back to their starting point. Lobell 205. 
contracts ${ }^{103}-$ a traditional method of operation which antedated the passage of the Investment Company Act. ${ }^{104}$ One of the specific issues faced in the drafting of that Act was whether this method of operation should be continued or banned. The decision to continue it, and to hedge it with appropriate protective conditions, was deliberate. ${ }^{105}$

As the legislative history shows, the planners of the legislation were well aware that in its formative period a fund cannot financially afford competent personnel. It must be endowed with services for which it cannot hope to repay until it grows large enough to support itself and, with a reasonable fee, afford some profit to its sponsors. Thus the choice, in the vast majority of cases, is not whether to have an advisory contract, or a paid staff, but whether to have a fund at all. One cannot conceive of competent men undertaking the expense of forming funds and nursing them through their growth periods without hope of eventual recompensation, and if successful, eventual profits. ${ }^{106}$ Yet those very profits are transformed, by the reasoning of both Brown $v$. Bullock and Meiselman v. Eberstadt, into a danger zone which one enters at the risk of review by a court which has undertaken the function of economic arbiter.

103. See Investment Dealers Digest-Annual Fund Review, Aug. 15, 1960.

104. See note 105 infra.

105. See Testimony of David Schenker, Senate Hearings on S. 3580, supra note 84 , at 252-testimony which reveals that, despite currents of feeling among the planners of the regulatory scheme and the drafters of the Act that there might be other alternatives to the advisory contract as a method of procuring management services for a mutual fund, the advisory contract would not be eliminated, but would be hedged with the appropriate protections now appearing in the Act. Mr. Schenker said,

People down in the Street have told me-people who control investment trusts [presumably referring to the then popular closed-end type of company as distinguished from mutual funds]. Why should this be any different from any other financial institution? They ought to have paid officers and paid directors.

Well that presented theoretically, at least, a potent argument. However, we made a detailed study of the industry. We found that although when you get into the large companies, they could afford to pay salaries of such size as to attract competent people and people with ability, on the other hand, when you get down to the smaller companies, in their cases, if you started paying salaries, those salaries would eat up all the ordinary income and all the profits.

So you had this situation: Should you abolish management contracts and say "Paid officers and directors"? Should you try to differentiate between large-sized companies and small sized companies?

Well, the Commission felt that under the circumstances if there were a few elementary safeguards set up with respect to management contracts, they could see no difficulty with that situation.

I know that this is not in accord with the views of many people in the Street. ... However, we said, "If the industry feels that the practice is indigenous to that type of institution, we may have some difficulty with it, but we would not recommend to this committee that the status be disturbed!"

106. See Testimony of Hugh W. Long before the Senate Subcommittee on S. 3580, supra note 84 , part 2 , at 587 . 
As the statute's proponents saw the problem, the need for regulation grew not out of the fact that funds were managed under contract rather than by internal personnel, but out of the highly fiduciary nature of the fund relationship and the need for provisions which would embody fiduciary standards in the handling of other people's money-in whatever form it was done. ${ }^{107}$ Fee rates higher than those involved in Brown v. Bullock and Meiselman v. Eberstadt were common ${ }^{108}$ and the attitude of the drafters towards fees was, not to regulate them, but to leave them to the weathering of disclosure and competition for investors' patronage.109

To alter a legislative philosophy so basic is, in our system, commonly regarded as a legislative and not a judicial function. Although the impact of their language is in that direction, the courts nowhere express any intention to remake the basic policy of the Investment Company Act or the structure of the institution. They may not have been aware of the possible consequencesto the meaning of the statute and the future of the institution regulated-of conclusions which in other contexts might be normal derivatives of normal expectations and assumptions.

\section{A Paraliel Opposite}

An interesting companion piece to Brown v. Bullock is Brouk v. Managed Funds, Inc., ${ }^{110}$ decided in January, 1961 by the Eighth Circuit. Despite the fact that the cases are in stark conflict in their approach to the problem of directors' liabilities both, in the author's view, illustrate the fallacy of using the typical corporate model as the conceptual basis for decisions affecting fund directors.

The Brouk case was a chapter in a story that began with an SEC investigation into malpractice of management leading to an extremely rare sanction-a stop order issued against a mutual fund.111 The long-standing adviser

107. It is instructive that of a 1,200 page volume (Part Three, Volume I) of the SEC's report on its study of investment companies, dealing with "Abuses and Deficiencies in the Organization and Operation of Investment Companies" (1940) only 50 pages were devoted specifically to the mutual fund (as distinguished from other types of investment companies) and in none of these is there contained any criticism of advisory contracts as methods of procuring investment service for the mutual fund, or of advisory fees. In Part Three, Chapter VII, management costs are treated in relation to size of the company. It is there shown that smaller companies cannot afford competent management unless they are endowed with such management. (pp. 2489-97).

108. See, e.g., Hearings on S. 3580, supra note 84, Part 2, at 707.

109. See notes 82 and 98 supra.

110. 286 F.2d 901 (8th Cir. 1961).

111. Managed Funds, Incorporated (SEC) Securities Act Release No. 4122, July 30, 1959. The "stop-order" is a sanction provided for in \$ 8(d) of the Securities Act of 1933, 48 Stat. 79 (1933), as amended, 15 U.S.C. \$ 77h(d) (1958) which empowers the Commission, after notice and opportunity for hearing, to terminate the effectiveness of a registration statement under the Securities Act, and thereby, stop sales of the security required to be registered. 
of the fund resigned under fire from the SEC ${ }^{112}$ and a battle between two competing replacement advisers led to a proxy fight. ${ }^{113}$ The complaints in the Brouk case alleged that the adviser had employed a partner of a New York brokerage firm as investment counsellor and manager of the Fund's portfolio under a 10-year contract calling for an aggregate of $\$ 425,000$ of salary to be applied against the brokerage commission channeled to the "counsellor"; that within a few years $\$ 1.5$ million of brokerage fees were channeled to the counsellor's firm; that the brokerage house paid $\$ 50,000$ a year for no apparent services to two associates of the adviser, one of them a director of the Fund and the other a relative of the principals in the advisory company; that the retaining of the "counsellor" was an act of delegation of duties of the adviser to another not under contract with the fund as required by statute; that a practice of paying predetermined periodic capital gains distributions resulted in a departure from the fund's investment policy, created excessive portfolio activity resulting in increased brokerage business channeled to the counsellor's firm and to persons who had rendered service to principals of the adviser. ${ }^{114}$ Violations of various provisions of the Investment Company Act and of the Investment Advisers Act of 1940 were alleged. ${ }^{115}$

The court devotes all but a few sentences of its opinion to whether privately asserted liabilities of directors may be predicated on violations of the Investment Company Act. It concludes that private causes of action do not arise from such violations. Except for a review of cases cited in contending briefs, the court reinforces its conclusion simply by noting that "the Investment Company and Advisers Acts neither make any definition of the duties of directors nor provide anywhere that a registered investment company may sue its directors." 110

Recognizing that the doctrine of "implied liability"117 has been employed under securities statutes in suits between buyers and sellers of securities, the court rejects the doctrine as applied to directors' liabilities. Its sole reference

112. See SEC Litigation Release No. 1786, September 27, 1960 (announcing the injunction issued by the District Court against the adviser to prevent it and its principals from serving as advisers for any registered investment company).

113. See Elliott, Shaken Trust, Barron's, April 4, 1960, p. 3.

114. In 1956, Managed Funds, Inc. experienced a portfolio turnover of $70 \%$, in 1957 the turnover was $44 \%$, and in $1958,97 \%$. These figures should be compared with corresponding average fund portfolio turnovers of $15.8 \%, 15 \%$ and $17.3 \%$ in the same respective years. SEC Release 4122, supra note 111, at 12 and n.11.

115. These included 54 Stat. 790 (1940), 15 U.S.C. $\$ 80 a-1$ (b) (2) (1958) (general declaration of policy); 54 Stat. 840 (1940), 15 U.S.C. § 80a-33 (1958) (publishing and circulating false statements); 54 Stat. 811 (1940), 15 U.S.C. $\$ 80 \mathrm{a}-13$ (1958) (departing from fundamental policy with shareholder assent); and 54 Stat. 812 (1940), 15 U.S.C. $\S 80 a-15$ (a) (1958) (serving as adviser without the contract required).

116. This language suggests that the suit could be brought in nomine the corporation as well as through derivative action.

117. I.e., the doctrine that, under certain circumstances a private right of action arises, by implication, from the violation of a statutory provision. See generally Loss, SECURITIES ReguzATION 1043-44 (1951). 
to the substantive aspects of the claims in dismissing the complaint is the following:

At common law directors are liable to exercise due care and are not insurers. The complaints here seek to hold these former directors to strict liability as insurers. The Act they rely on not only contains no such provision but plainly negates an intent to create such an innovation. ${ }^{118}$

Thus, even treating the statutory violation allegations as surplusage, the court deemed no facts to have been pleaded giving rise to a claim for which relief could be granted. 119

The complaint in the Brouk case, unlike that in Brown v. Bullock and the fifty similar actions now pending in various state and federal courts, involves claims based on aspects of fund operation which, in terms of the doctrine of Hun v. Cary, may be deemed prima facie within the area of mandated responsibility. ${ }^{120}$ If the duties asserted in the Brouk case exist at all, they exist somewhere in the adviser-director complex of the Fund.

The court presumably did not deny the existence of these duties. The opinion is limited in its application to directors, and the complaint was dismissed only as it affected the unaffiliated directors of the Fund. No one can seriously deem a fund director liable for every error, or even act of malpractice by the adviser that takes place. However, whether or not the complaint in fact seeks to make "insurers" of the directors is not discernible from the face of the complaint.

Faced with two opposite opinions like those in the Brouk and Brown cases, the bar may well wonder where to find its guides in this relatively new field. The door to proof that the Brouk case closed to the plaintiffs, the Brown case opened wide. The plaintiff in the Brouk case might have proved a failure of duty in fund directors. The plaintiff in the Brozen case could establish "conversion" or "breach of trust" only by proving facts he never alleged ${ }^{121}$ and only if the court is willing to substitute itself for the market place, the investor and the director in weighing the "worth" of the advisory service. The contrast of the two cases illustrates ironically the deficiencies in the approaches courts have thus far taken to the modern mutual fund. ${ }^{122}$ The Brozen case upholds allegations of violation of provisions of the Act on their face endowing the Commission, and the Commission only, with authority to pursue

118. 286 F.2d 901, 918 (8th Cir. 1961) (citation omitted).

119. But see Lutz v. Boaz, Civil No. 1147, Del. Ch., New Castle County, May 25, 1961.

120. See note 30 supra and accompanying text.

121. This statement refers not only to the conclusory nature of the allegations in the Brown case, but also assumes the author's view that a complaint as to an unmandated responsibility (a term of the arrangement disclosed to and accepted by the shareholder) cannot be made without alleging inter alia a change in circumstance so as, in effect, to create new terms materially different from those disclosed and accepted.

122. Differences in pleading practices between federal and Delaware courts, while they may have served to heighten the contrast, certainly cannot provide a complete explanation for it. 
remedies. ${ }^{123}$ Allegations which were not so limited are struck down in the Brouk case as ill-pleaded. ${ }^{124}$

Both opinions seem to presume the conceptual model of the typical corporation. While their differences in result can be attributed to the differences in the views of the judges as to the attributes of the typical corporate model, they illustrate, as this anthor views them, the fallacy of working from the wrong model. Neither of two cars, crossing on an east-west road, is going north.

\section{Statutory Violations and Private Causes of Action}

Whether or not a violation of statute gives rise to a private cause of action was the question occupying most of the attention of the judges in both the Brown and Brouk cases. Their expressed views, as we have noted, are directly contrary. While only tangential to the main problem of directors' liabilities, this issue is an important one. For it may bear not only on the scope of the rights that can be asserted in private litigation or the court in which those rights may be asserted, but affects vital allocations of governmental functions as well. ${ }^{125}$

It is, however, enormously difficult to reduce the problem to manageable size-even if limited to the Investment Company Act. For this is a field in which what judges say may have very little to do with what they mean. With distressing frequency judges say they are upholding complaints alleging statutory violations when it seems that in fact they are simply content that the complaint states a cause of action at common law and are merely setting up a hook on which to hang federal jurisdiction or when (assuming diversity or other independent ground of federal jurisdiction) the statutory pleading is

123. E.g., Section 36 of the Investment Company Act, 54 Stat. 841 (1940), 15 U.S.C. \& 80a-35 (1958), which says that "The Commission is authorized to bring an action" to prevent gross misconduct or gross abuse of trust. The court also cites with approval Taussig v. Wellington Fund, Inc., 187 F. Supp. 179 (D. Del. 1960), which held a violation of $\S 35$ (d) properly pleaded in a private action. That section provides:

(d) It shall be unlawful for any registered investment company hereafter to adopt as a part of the name or title of such company, or of any security of which it is the issuer, any word or words which the Commission finds and by order declares to be deceptive or misleading. The Conmission is anthorized to bring an action in the proper district court of the United States or United States court of any Territory or other place subject to the jurisdiction of the United States alleging that the name or title of any registered investment company, or of any security which it has issued, is materially deceptive or misleading. If the court finds that the Commission's allegations in this respect, taking into consideration the history of the investment company and the length of time which it may have used any such name or title, are established, the court shall enjoin such investment company from continuing to use any such name or title.

54 Stat. 840 (1940), 15 U.S.C. $\$ 80 a-34$ (d) (1958) (emphasis supplied).

124. Neither $\$ \$ 33$ nor 13 , nor 15 expressly limit the pursuit of remedies to the Commission, as do $\S 336$ and $35(\mathrm{~d})$.

125. See Doyle v. Milton, 73 F. Supp. 281, 284-85 (S.D.N.Y. 1947). 
actually surplusage. ${ }^{126}$ Sometimes, as in the Brouk case, elaborate discussions of the issue boil down to nothing more than the mere conclusion that no violation has been alleged. One may pair together cases like Brozon and Meiselman which deal with almost identical issues--the first case turning its reasoning almost wholly on questions of statute, the second never mentioning the statute. $^{127}$

On the other hand, one may pair decisions like those in the Brown and Brouk cases. In the first, the court seems willing to accept sweeping allegations of statutory violation-even of provisions clearly allocating the prosecution function to a specific governmental agency (for example, section 36 of the Investment Company Act) and to open an "administered" statute to the hazards of private litigation under varieties of theory and skill of counsel, not always consistent, and not always bent on the statutory purpose as their ultimate aim. In the second, the court's dicta seem to close completely the gates of private litigation under the very same Act.

Where a statute specifically creates private causes of action, the problem does not arise. ${ }^{128}$ It arises when a statute prescribes a duty but does not specifically designate it to be enforceable in private litigation ${ }^{120}$-or when it vests power to pursue remedies in one class of persons without expressly excluding others. ${ }^{130}$

The bases on which the pleading of statutory violation will be upheld have

126. In Taussig v. Wellington Fund, Inc., 187 F. Supp. 179 (D. Del. 1960), the court entertained a pleading of violation of $\S 35$ (d) of the Investment Company Act to bring into play the doctrine of pendent jurisdiction. Thereafter the Court practically ignored the section and turned its reasoning almost wholly on considerations of trade mark law. Typical also is Roosevelt Field, Inc. v. Town of North Hempstead, 84 F. Supp. 456 (E.D.N.Y. 1949) where an old fashioned nuisance was condemned under a provision of the Air Commerce Act of 1946 requiring notice to a federal agency of proposed construction along airways. But see Howard v. Furst, 238 F.2d 790 (2d Cir. 1956), cert. denied, 353 U.S. 937 (1957), where the court refused to assert jurisdiction in a case lacking diversity, solely under a pleading of violation of SEC's proxy rules.

A refreshing contrast to these cases is Dederick v. North American Co., 48 F. Supp. 410 (S.D.N.Y. 1943) which acknowledged that both the court and the SEC had jurisdiction over certain inter-company claims in a public utility holding company system but in which the judge, exercising his power over the court calendar, delayed consideration of the litigation before him until the administrative proceedings were over on the possibility that nothing might be left to litigate.

127. The fact that the Meiselman case was a state court case, whereas the Brozen case was in the federal court is of little significance. Section 44 of the Investment Company Act of 1940 confers on state courts, concurrently with federal courts, jurisdiction of actions under the act. 54 Stat. 844 (1940), 15 U.S.C. $\$ 80 \mathrm{a}-43$ (1958).

128. See, e.g., Securities Act of $1933 \S \S 11,12,15$ and 16, 48 Stat. 82, 84, as amended, 15 U.S.C. $\$ \S 77 k, 1$, o, p (1958) ; Securities Exchange Act of 1934 § 16(b), 48 Stat. 896, 15 U.S.C. $\S 78 \mathrm{p}(\mathrm{b})$ (1958).

129. Such, for example, are almost all the duty-prescribing provisions of the Investment Company Act.

130. See, e.g., $\S \S 35$ (d) and 36 of the Investment Company Act of 1940, 54 Stat. 840, 841,15 U.S.C. $\$ \S 80 a-34$ (d), 80a-35 (1958). 
been variously stated. ${ }^{132}$ All, however, are comprehended within Loss' characterization of the pattern as the "growth of the law by the interaction of legislators and judges."132 From the tone of many of the decisions upholding the implied right of private action for statutory violation one is led to feel that the court, regarding itself as an agency of government, is consciously carrying forward a legislative purpose with which it agrees and which it deems socially important. ${ }^{133}$

The Brown case is a unique adventure into "interaction" not merely between judges and legislators, but between judges and administrators-one that raises fundamental problems in the meaning of the administrative process. The Securities and Exchange Commission filed a memorandum as amicus curiae in that case in support of the plaintiffs' contention that violations of statute may give rise to private causes of action. It expressly refrained from taking any position on the question whether the complaint stated a cause of action (i.e. whether violations were alleged) but stated without elaboration that

It may be noted that while the Act does not undertake to regulate management fees, it does not follow that there cannot be a gross abuse of trust with respect to fees.

The SEC's position in the Brown case has curious overtones. Whether or not the court held that violation of statute gives rise to private causes of action, the SEC's primary duty to enforce sections 36 and 37 continues. If the SEC deemed that either wilful conversion or gross abuse of trust existed in the matter, it had not only the authority but the clear duty to bring an injunctive action in its own name as plaintiff and perhaps to have referred the matter to the Department of Justice for prosecution. That it never did so because of a belief that neither section 36 nor 37 was violated seems indicated by the fact that it has never sought to enjoin any fund or fund adviser or director from complying with an advisory contract because the fee was too high. It has accepted the registration statements of more than two hundred funds, most with aggregate fees higher than those involved in the Brown case, and has cleared thousands of prospecti disclosing higher fees. It has never intimated that any of these prospecti was deficient for failing to reveal even the possibility that the fee might involve a conversion or abuse of trust. It has been aware, since before passage of the Act, that funds are formed by

131. In addition to the "void contract" and "tort" theories mentioned by Loss, op. cit. supra note 117, at 1043-44, is a variety of policies such as "the law-enforcement aspects of private litigation based on statutory violations." Brown v. Bullock, Civil 'No. 60-3106, 37, S.D.N.Y., March 9, 1961. See Baird v. Franklin, 141 F.2d 238 (2d Cir. 1944) (cause of action stated by complaint against stock exchange executives for the peculations of the president of the exchange based on provisions of the Securities Exchange Act of 1934 requiring exchanges to adopt rules of fair dealing) (dictum).

132. Loss, op. cit. supra note 117 , at $1044-45$ adds "It is all a matter of 'legislative intention.' The courts have to be sure that they are only 'finding' not 'making' the law."

133. See, e.g., Baird v. Franklin, 141 F.2d 238 (2d Cir. 1944). 
advisers, ${ }^{134}$ that advisers have, as they must, a dominant voice on fund boards of directors and that directors who undertake to serve on a fund board do so without a determination, tacit or otherwise, to destroy the relationship between the shareholder and the adviser because of a difference over the question of fees. Nothing alleged or provable in Brown v. Bullock was either unknown or unknowable to the SEC or unamenable to direct corrective action by it.

If the SEC accepts the philosophy of Brown v. Bullock, it confesses that for twenty years it has misinterpreted the statute it drafted and recommended to the Congress. If the SEC rejects the philosophy of Brown v. Bullock, it is in the anomalous position of having, as a friend of the court, led the court through the main gate of the litigation (the question whether violation of the Act gives rise to a cause of action) but of having abandoned it before the dual doors of "Cause Stated" and "Cause not Stated" allowing the court to enter through the door which the Commission privately deems to be the wrong one.

\section{Conclusion}

The author has tried to show that at the threshold of an appraisal of shareholder rights and directors' duties in the mutual fund one must allocate responsibilities according to 1) a conceptual model of the fund that takes into account the unique relationship established, and the aims sought, in fund investing and 2) a willingness to go behind black letter generalizations about duties and immunities of directors generally and to test them for their aptness to the fund situation specifically. The prime line of allocation is between disclosed and accepted "term" aspects of funds (or unmandated responsibilities) and operational aspects of funds (or mandated responsibilities). Warrant for such division exists not only in the basic doctrine from which fiduciary obligations in freely chosen arrangements spring, but in the fundamental pattern of the statutes applicable to the mutual fund. To fill gaps in the statute with prescriptions foreign to this pattern distorts both the legislative intent and underlying expectations and understandings inherent in fund investment.

134. See "Investment Trusts and Investment Companies," SEC Report on its study, 1940, part 3, p. 803. 


\section{THE YALE LAW JOURNAL}

\begin{tabular}{lll}
\hline VOLUME 70 & JULY 1961 & NUMBER 8 \\
\hline
\end{tabular}

\section{RoBERT E. Hudec \\ Editor-in-Chief}

Neale M. Albert

LAWRENCE G. GOOdMAN

DaVID M. TRUBEK

JERE A. Young

Note \& Comment Editors
Burton J. AHrens

Hershel Y. Allerhand

Douglas R. Ayer

Charles S. Battles, Jr.

HENRY G. BISGaIER

JosepH S. BoRUS

Thomas B. Bracken

Carroll W. Brewster

Stephen A. Brown

ALan M. Dershowitz

JAN DeUTSCH

GEORGE B. DRIESEN

BENJAMIN S. DuVAL, JR.

JOEL J. FINER

\author{
Harrison J. GoLdrN \\ Article \& Book \\ Review Editor \\ SIDNEY M. WOLINSKY \\ Topics \& Case \\ Editor
}

\section{Peter R. TAft \\ Managing Editor}

JAMES O. FREEDMAAN

JAMEs H. Gillespie

David I. GoldblatT

Wilitam S. Greenawalt

DAvid C. Greer

JoEN P. HeINZ

Algernon S. Holderness, JR.

ARTHUR P. JACOBS

Philip F. Johnson

RoBert A. JoHNSON

Peter G. KeILY

LAWRENCE P. KIAATON

ZANE KIEIN

George Lefcoe
Alan H. LeVtne

Charles E. Lewis John T. Marshall James L. MitchelL

Thonas S. Nichols

Peter G. Platt

Stoddard D. Platt

Charles F. Richards, JR.

David A. Rosen

SidNEy G. Saltz

Robert M. SHepard

Carol W. Trencher

AdaM WaLINSKY

HARRX J. WeXLER

MARIE MCMAHON

Business Secretary

\section{CONTRIBUTORS TO THIS ISSUE}

Nathan D. Lobelx. B.S.S., C.C.N.Y., 1934, LI.B. Columbia, 1937. Member of the New York Bar.

Clyde W. Sunarers. B.S. 1939, J.D. 1942, University of Illinois; LL.M. 1946, Columbia University. Professor of Law, Yale University.

Stephen L. Dinces. A.B. 1958, Amherst College. Third Year Student, Yale Law School.

Christopher D. Stone. A.B. 1959, Harvard University. Second Year Student, Yale Law School. 